\title{
METHODOLOGICAL PROPOSAL FOR THE ANALYSIS OF THE EVOLUTION OF GLACIERS SINCE THE LITTLE ICE AGE AND ITS APPLICATION IN THE TRÖLLASKAGI PENINSULA (NORTHERN ICELAND)
}

\section{J.M. FERNÁNDEZ-FERNÁNDEZ*, N. ANDRÉS}

High Mountain Physical Geography Research Group, Department of Geography, Complutense University of Madrid, 28040 Madrid, Spain.

\begin{abstract}
In this paper we propose a methodological sequence for the study of glaciers and climate change, and for the use of glaciers as indicators of climatic evolution. Our proposal includes different techniques focused on: mapping glacier extents at different dates, measuring front variations, calculating areas and volumes, analyzing glacier Equilibrium-Line Altitudes (ELA), statistical treatment of climate series, and the application of glacier-climate models that relate temperature and precipitation and enable paleoclimate reconstruction. This methodology was tested by remote monitoring of three highly sensitive debris-free glaciers in the Tröllaskagi peninsula (northern Iceland) since the end of the Little Ice Age (LIA), and the results show an average retreat of $1.3 \mathrm{~km}$ as well as a reduction in area and volume of $25 \%$ and $33 \%$ as a result of the warming that began at the end of the LIA. The application of the glacier-climate models suggests a climate that was up to $49 \%$ less humid at the LIA maximum. The bibliographic review of the methods utilized enables us to validate our methodological proposal and the results obtained, and ensures its application in different areas of study.
\end{abstract}

Propuesta metodológica para el análisis de la evolución de los glaciares desde la Pequeña Edad del Hielo y su aplicación en la Península de Tröllaskagi (Norte de Islandia)

RESUMEN. En este trabajo se propone una secuencia metodológica para estudiar el impacto del cambio climático en los glaciares y su respuesta, así como para utilizar los glaciares como indicadores de evolución climática. Nuestra propuesta integra diferentes técnicas centradas en: la cartografía de la extensión de los glaciares en diferentes fechas, las mediciones de las variaciones del frente, el cálculo de superficies y volúmenes, el análisis de la altitud de la línea de equilibrio glaciar (ELA), el tratamiento estadístico de series climatológicas, y la aplicación de modelos glacio-climáticos que relacionan temperatura y precipitación, y posibilitan las reconstrucciones paleoclimáticas. 
Esta propuesta se ha experimentado en el seguimiento de tres glaciares libres de derrubios altamente sensibles de la península de Tröllaskagi (norte de Islandia) desde el final de la Pequeña Edad de Hielo (PEH), y los resultados evidencian un retroceso medio de 1,3 km, así como una reducción de superficie y volumen del $25 \%$ y 33\%, como consecuencia del calentamiento iniciado al final de la PEH. La aplicación de los modelos glacio-climáticos sugiere un clima hasta un 49\% menos húmedo en el máximo de la PEH. La revisión bibliográfica de los métodos empleados nos permite validar nuestra propuesta metodológica y los resultados obtenidos, y garantiza su aplicación en áreas de estudio contrastadas.

Key words: glaciers, climatic change, paleoclimatic reconstruction, Little Ice Age, Tröllaskagi, Iceland.

Palabras clave: glaciares, cambio climático, reconstrucción paleoclimática, Pequeña Edad de Hielo, Tröllaskagi, Islandia.

Received: 3 August 2017

Accepted: 26 October 2017

* Corresponding author: José M. Fernández-Fernández, High Mountain Physical Geography Research Group, Department of Geography, Complutense University of Madrid, 28040 Madrid, Spain.E-mail address: josemariafernandez@ucm.es

\section{Introduction}

Glaciers respond to climatic variability through changes in their length, area, volume, thickness and flow rate (Francou and Vincent, 2010; Gabbud et al., 2016). In this sense, they are highly sensitive to variations in summer temperature and winter precipitation, as these are the variables that to a greater extent control ablation and accumulation (see Ahlmann, 1924; Liestøl, 1967; Sutherland, 1984; Ohmura et al., 1992) respectively, and therefore affect the sign of mass balance and largely -but not exclusively (Gabbud et al., 2016) - front dynamics. Nevertheless, although glacier advance and retreat are considered to be indicators of climate change, it is crucial to understand the relationships between climatic variations and glacier response (Úbeda, 2011; Gabbud et al., 2016; Mal et al., 2016). The complexity of the interaction between glaciers and the climate system requires the establishment of a methodology that can analyze glacier oscillations and their relation to climate from different points of view and in an interrelated manner.

Changes in the positions of glacier fronts (i.e. retreat) are one of the indicators of climate warming and glacier change (Houghton et al., 1996; Gabbud et al., 2016) that are the simplest to measure, traditionally by placing markers or stakes that record the position of the fronts at different dates (Eythorsson, 1931, 1935; Caseldine and Cullingford, 1981; Caseldine, 1983; Caseldine, 1987; Sigurðsson, 1998; Sigurðsson et al., 2007; Icelandic Glaciological Society, 2015). The records of glacier lengths, combined with climate sensitivity and response times, are also valuable proxies for the reconstruction of temperature histories, as shown by Oerlemans (2005). 
The development of Geographic Information Systems (GIS) and remote sensing have enabled the remote study of glaciers by using aerial photographs and satellite images (see Kääb, 2005; Kääb et al., 2005; Bradwell et al., 2006; Bahuguna et al., 2007; Pellika and Rees, 2010; Chandler et al., 2016; Gachev et al., 2016), which has improved the recording of glacier surface trends (e.g. Thompson et al., 2011; Gjermundsen et al., 2011; Kaldybayev et al., 2016; Veettil et al., 2017; Fernández-Fernández et al., 2017). Estimating glacier volumes and their spatiotemporal variations are also key aspects in the research on the impact of climate change, since the quantification of glacier melt is essential in modelling due to its global contribution to rising sea levels (Church et al., 2001; Braithwaite et al., 2006). The difficulties of accessing glaciers and surveying them through radio echo-sounding have led to the fact that estimates of volume and its variations are often carried out indirectly by applying mathematical models with a physical basis (Chen and Ohmura, 1990; Bahr et al., 1997; Klein and Isacks, 1998; Farinotti et al., 2009), because they are so easy to implement. In other cases planimetric measurements (e.g. Holmlund, 1987), remote sensing (e.g. Bahuguna et al., 2007; Rabatel et al., 2016), and the combination of GIS and photogrammetry (e.g. D'Agata and Zanutta, 2007; Diolaiuti et al., 2009; Hannesdótir et al., 2015; Gabbud et al., 2016) have been used.

The joint study of glacier trends and climate is essential in order to assess the impact of climate change on glaciers, as well as their response to climate fluctuations. Thus, for example, the close relationship between front position variations and summer temperature oscillations is well known (Caseldine, 1985b; Kirkbride, 2002; Bradwell, 2004; Bradwell et al., 2013). Of equally vital importance is an understanding of the climatic conditions that favor or preserve glaciation by applying glacier-climate models at the EquilibriumLine Altitude (ELA) (e.g. Ballantyne, 1989; Ohmura et al., 1992; Braithwaite, 2008). These models are especially useful to carry out paleoclimate reconstruction at various time scales (Ballantyne, 1989; Dahl and Nesje, 1992; Caseldine and Stötter, 1993; Hughes, 2009a; Hughes et al., 2006, 2010; Hughes and Braithwaite, 2008; Meyer and Barr, 2017) or even to explain the existence of glaciers in marginal areas that are not favorable for glaciation, especially in terms of the amount of accumulation required to make up for ablation (e.g. Hughes, 2009b; Colucci, 2016), or to interpret the effect of extreme climatic events on glaciers (e.g. Hughes, 2008). Lastly, mention should also be made of the work of Fernández-Fernández et al. (2017), who use several indicators of morphological changes in glaciers and relate them to climate records while applying different models to reconstruct the response of glaciers to climatic changes.

This article integrates a methodological sequence that complements most of the indicators and techniques presented in order to analyze the impact of climate change on glaciers and their response based on the analysis of different variables. Therefore, the objective of this study is to propose and evaluate a methodological approach applied in a particularly sensitive area where glaciers dynamically respond to the changes in the elements that make up the climate (Andrés et al., 2016), and applicable in any area of study. To illustrate the methodology, three glaciers have been selected (Gljúfurárjökull and Western/Eastern Tungnahryggsjökull) which are located in the interior of the Tröllaskagi Peninsula (northern Iceland). 


\section{Area of application}

In order to evaluate the applicability of the methods we sought an area whose geographic configuration makes it particularly sensitive to climate change and therefore turns it into an experimental area for analyzing the response of glaciers. An area with these characteristics is the Tröllaskagi Peninsula (northern Iceland) because it is the meeting place of the main atmospheric masses (masses of cold arctic air and of temperate subtropical air) and ocean currents (the cold polar East Greenland Current and the relatively warm Irminger Current) that determine the ocean-atmosphere interaction of the North Atlantic.

The Tröllaskagi Peninsula extends latitudinally between the Atlantic Ocean at $66^{\circ} 12^{\prime} \mathrm{N}$ (cape of Siglunes) and the central plateaus $\left(65^{\circ} 23^{\prime} \mathrm{N}\right)$, and longitudinally between the fjords of Skagafjörður (19³0' W) and Eyjafjörður (18 $10^{\circ}$ ' W), which separate it from the Skagi and Flateyjarskagi peninsulas respectively (Fig. 1). It is a $4000-\mathrm{km}^{2}$ plateau resulting from the accumulation of successive layers of Miocene basalts belonging to the Tertiary Basalt Formation, interspersed with reddish sedimentary strata (paleosols) (Sæmundsson et al., 1980; Jóhannesson and Sæmundsson, 1989). The plateau culminates at altitudes between 1000 and 1500 meters above sea level (Kerling, $1536 \mathrm{~m}$ ) and is dissected by deep valleys with steep slopes whose headwaters now function as glacial cirques. These cirques shelter over 160 small glaciers, mostly north-facing, resulting from the leeward accumulation of snow coming from the plateau (Caseldine and Stötter, 1993) and reduced exposure to solar radiation. Most of them are rock glaciers and debriscovered glaciers, due to the intense paraglacial activity affecting the walls (Andrés et al., 2016). These glaciers are characterized by almost static behaviour because the insulating effect of their debris cover leaves them with little or no sensitivity to the climate (Martin et al., 1991). Only a minority of glaciers lack surface debris cover and this makes them highly dynamic and sensitive to climate oscillations, especially summer temperature (Caseldine, 1985b; Häberle, 1991; Kugelmann, 1991).

Tröllaskagi's climate is characterized by a mean annual air temperature (MAAT) of 2 to $4{ }^{\circ} \mathrm{C}$ at sea level, dropping to between -2 and $-4{ }^{\circ} \mathrm{C}$ at the summits (Etzelmüller et al., 2007). At Akureyri, in the east of the peninsula, and at the mouth of the Eyjafjarðardalur, the MAAT of the $1901-1990$ series is $3.4{ }^{\circ} \mathrm{C}$, whereas in the three months of summer the temperature can reach $8.4{ }^{\circ} \mathrm{C}$ (Einarsson, 1991). Annual precipitation (1971-2000) ranges from $400 \mathrm{~mm}$ at lower altitudes to $2500 \mathrm{~mm}$ at the summits (Crochet et al., 2007).

The frontier location of Icelandic glaciers in regard to atmosphere and ocean systems makes them exceptionally sensitive to climate oscillations (Brynjólfsson et al., 2015) as well as reliable indicators of climatic evolution and the impact of climate change (see Jóhannesson and Sigurðsson, 1998; Bradwell et al., 2004; Geirsdóttir et al., 2009; Chandler et al., 2016; Fernández-Fernández et al., 2017). Therefore, in order to ensure maximum climate sensitivity and reliability, we selected three small debris-free glaciers (4 and $7 \mathrm{~km}^{2}$ surfaces) with no record of having experienced surges: namely Gljúfurárjökull, and Western and Eastern Tungnahryggsjökull, located in the central sector of the Tröllaskagi peninsula (Fig. 1). Gljúfurárjökull (6542’41” N, 18³9'29” W) is located at the head of the Gljúfurárdalur valley, an eastern tributary of Skíðadalur that belongs to the Svarfaðardalur river system. The Western (65\%41'3' N, 18 52 '34" W) 
and Eastern (65'41'23" N, 18 48'38” W) Tungnahryggsjökull glaciers are located in the Vesturdalur and Austurdalur valleys respectively, which are separated by the crest of Tungnaryggur and are tributaries of Kolbeinsdalur.

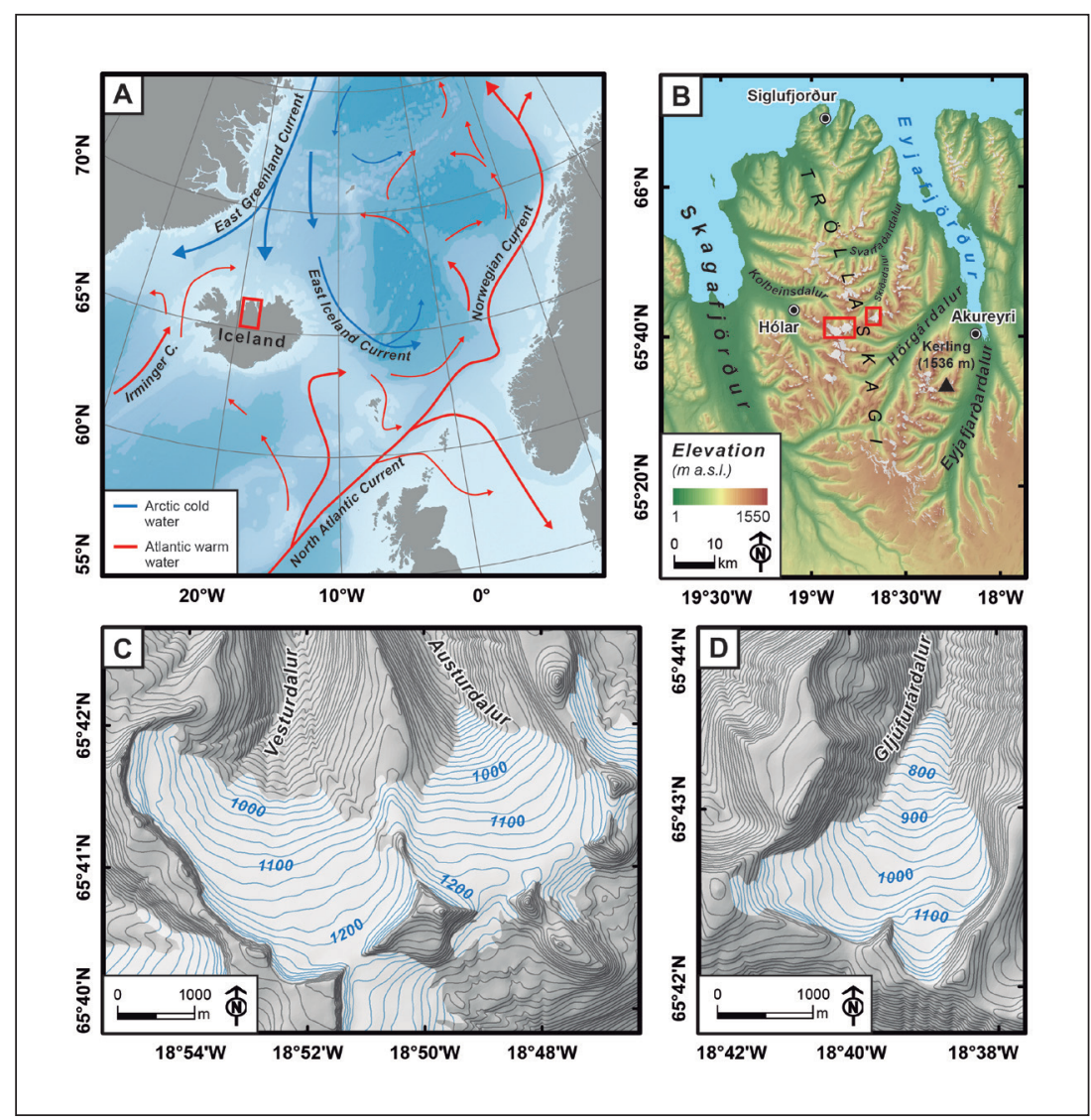

Figure 1. Location of the study area. A. Iceland at the North Atlantic in the context of the meeting of cold and warm sea currents (modified from Institute of Marine Research, Norway, 2017). B. Situation of the Tröllaskagi peninsula and the glaciers analyzed (red boxes). C and D panels correspond to the enlarged boxes with the surrounding areas of Tungnahryggsjökull and Gljúfurárjökull glaciers, respectively.

\section{Methodology}

The effect of climate change since the termination of the LIA has been analyzed from different points of view, mainly including: measuring retreat and advance based on variations in the fronts position; changes in area and volume (estimated); reconstruction of glacier surfaces; calculation and time analysis of the ELAs; statistical treatment of climate series; and the application of glacier-climate models to estimate precipitation in the ELA. 


\subsection{Front variations and advance-retreat measurement}

Trend analysis of glacier geometry was used as an indicator of changing climate (Bahr et al., 1997). The study was carried out in the ArcGIS 10.3 (Esri) GIS work environment. The work started by identifying the positions occupied by the glacier fronts during LIA maximum, as established and validated in the literature (Caseldine and Cullingford, 1981; Caseldine, 1983, 1985a, 1985b; Caseldine and Stötter, 1993) by applying lichenometric dating methods to blocks of the most advanced moraine formations. Monitoring of the glacier extents after the LIA was based on the photointerpretation of aerial photograms (approximate scale 1:30,000) of the glaciers in 1946 (photographs taken by the United States Army Map Service), 1985 and 1994; an orthophotograph from the year 2000; and a SPOT satellite image from 2005 provided by the National Land Survey of Iceland. The photointerpretation was combined with visits to the glacier fronts in successive field campaigns in 2012, 2013, 2014 and 2015 (Figs. 2, 3 and 4). The photograms were georeferenced on the orthophotograph of 2000, only for a rectangular part that includes the area surrounding the glaciers. In order to accurately observe the variations of the fronts between dates, a large number of control points (53-171) were established, evenly distributed in easily identifiable elements such as the indentations and protrusions of the topmost surfaces of the plateaus and cirque walls, as well as confluences of beds or channels of debris flows in the slopes. The "Adjust" rectification method was chosen instead of thirdorder polynomial transformation due to: 1) the joint optimization of the global root mean squared (RMS) error and the positional accuracy of the control points (local precision); and 2) less deformation of the geometry of glacier tongues and fronts, in order to ensure that the positions of the fronts were reliable and comparable between dates. Third-order polynomial transformation only optimizes overall accuracy and not local accuracy, which is particularly important at the control points established in the vicinity of glacier fronts. RMS errors resulting from georeferencing through "Adjust" transformation ranged from 3 to $6 \mathrm{~m}$ and were lower than those obtained from the other transformations (Table 1).

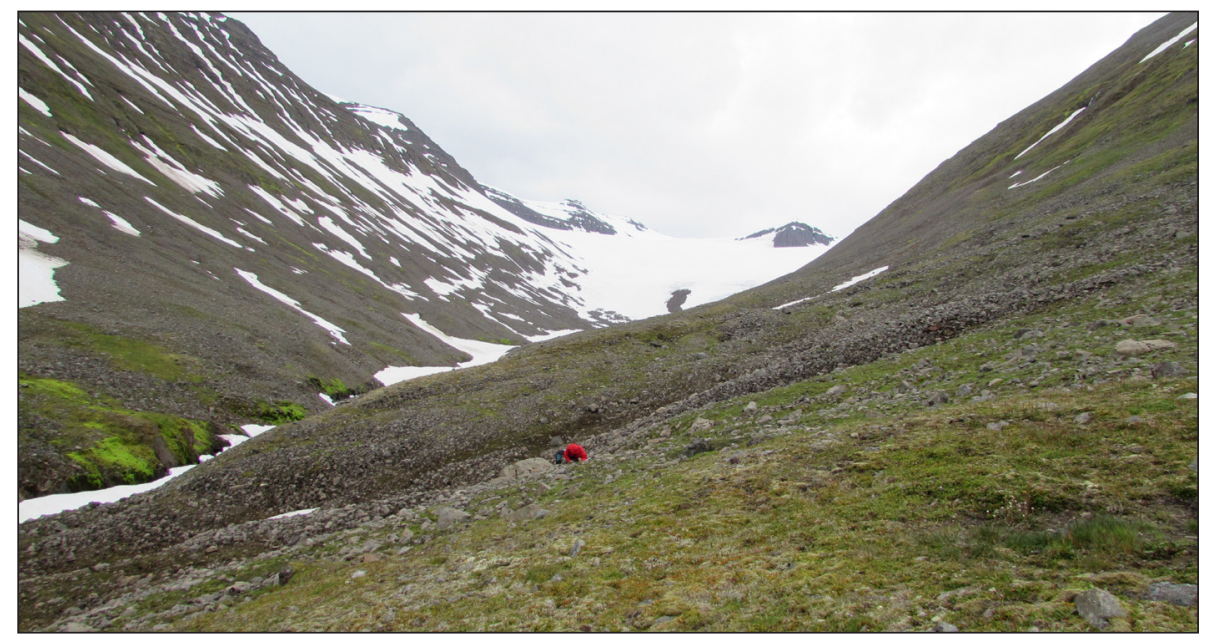

Figure 2. View of the Gljúfurárjökull snout from the left 'Little Ice Age' moraine. 


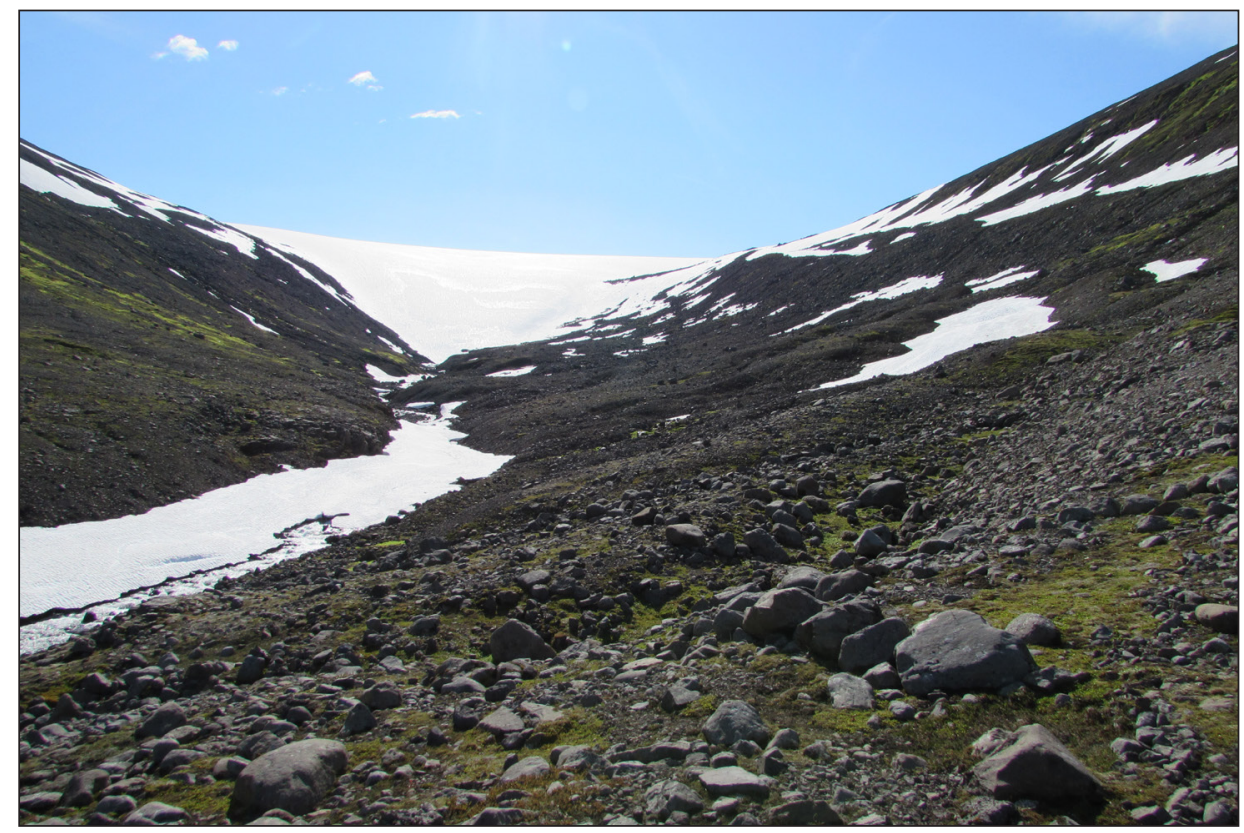

Figure 3. View of the Eastern Tungnahryggsjökull snout from the left 1946 moraine. A number of ridges can be seen in the foreland, which shows the pulsating behaviour of the glacier in response to the recent climatic fluctuations.

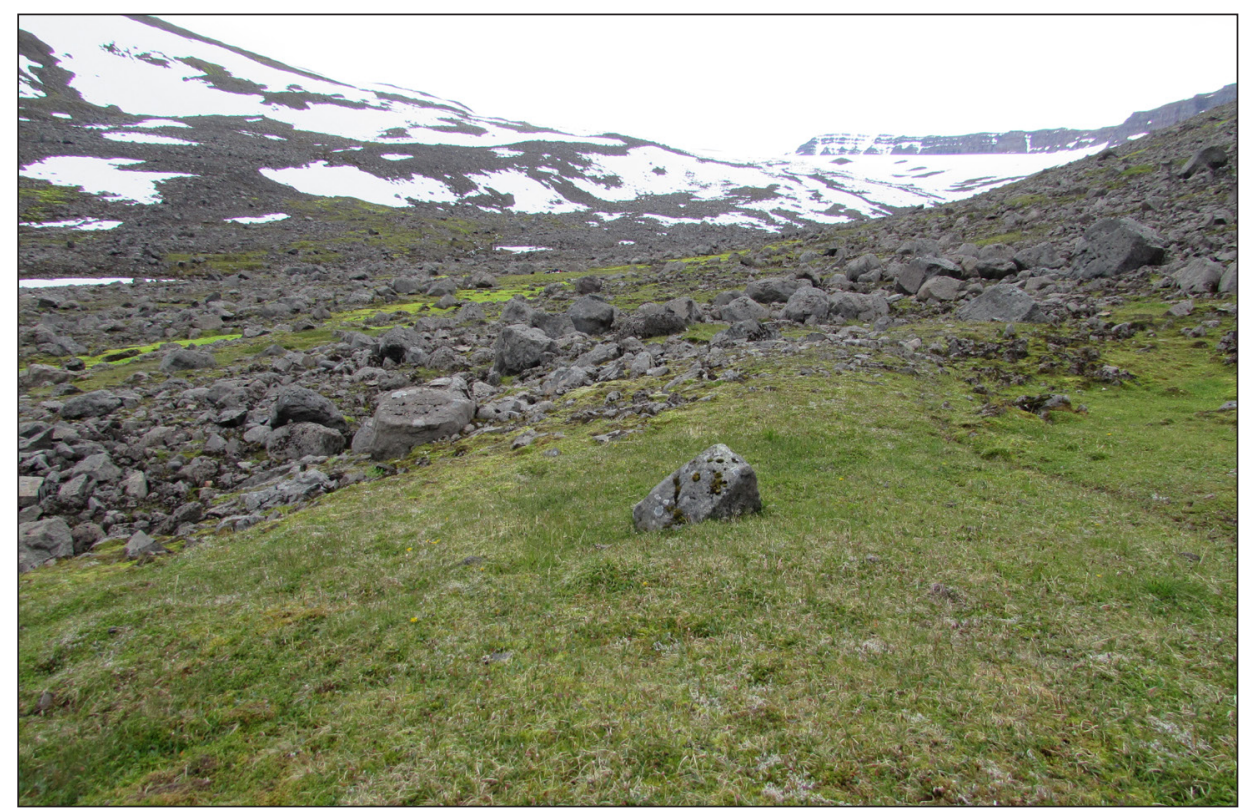

Figure 4. View of the Western Tungnahryggsjökull glacier from the 'Little Ice Age' moraine. 
Table 1. Summary of control points used in the georeferencing of the aerial photos and RMS error derived from the different georeferencing methods in each date. "Pol." refers to the polynomial transformation and the number to its order; "Adj." refers to the "Adjust" method. RMS error is expressed in meters.

\begin{tabular}{|c|c|c|c|c|c|c|c|c|c|c|c|c|c|c|c|}
\hline & & & 1946 & & & & & 1985 & & & & & 1994 & & \\
\hline Glacier & $\begin{array}{l}\text { No. } \\
\text { ctrl. } \\
\text { pts. }\end{array}$ & $\begin{array}{c}\text { Pol. } \\
1\end{array}$ & $\begin{array}{c}\text { Pol. } \\
2\end{array}$ & $\begin{array}{c}\text { Pol. } \\
3\end{array}$ & Adj. & $\begin{array}{l}\text { No. } \\
\text { ctrl. } \\
\text { pts. }\end{array}$ & $\begin{array}{c}\text { Pol. } \\
1\end{array}$ & $\begin{array}{l}\text { Pol. } \\
2\end{array}$ & & Adj. & $\begin{array}{l}\text { No. } \\
\text { ctrl. } \\
\text { pts. }\end{array}$ & $\begin{array}{c}\text { Pol. } \\
1\end{array}$ & $\begin{array}{c}\text { Pol. } \\
2\end{array}$ & $\begin{array}{c}\text { Pol. } \\
3\end{array}$ & Adj. \\
\hline Gljúfurárjökull & 128 & 96 & 80 & 68 & 4 & 103 & 108 & 76 & 54 & 6 & 171 & 110 & 82 & 63 & 6 \\
\hline Tungnahryggsjökull (W) & 78 & 66 & 48 & 31 & 3 & 78 & 67 & 35 & 28 & 4 & 90 & 77 & 53 & 42 & 5 \\
\hline Tungnahryggsjökull (E) & 87 & 58 & 51 & 34 & 5 & 53 & 76 & 39 & 27 & 6 & - & - & - & - & - \\
\hline
\end{tabular}

Once the photographs were georeferenced, the geometry of the glacier tongues was mapped at a scale of 1:1000 by means of vector polygon layers (Fig. 5). When mapping the glaciers' extent at the various dates the geometry of the accumulation zone (head) of the glaciers in 1946 was preserved, according to Koblet et al. (2010), assuming that the actual changes in the extent of the accumulation zone are smaller than the differences derived from the operator. Front advance or retreat was measured in 3D on the digital elevation model (DEM) and the layers of glacier geometry, in the ArcScene work environment, with the "Measure Direct 3D Line" tool. In the case of simple fronts that were clearly tongue-shaped and had a well-defined apex, such as those of Gljúfurárjökull and Eastern Tungnahryggsjökull, the distance of retreat or advance between different dates was measured between the most advanced points of the fronts at the various dates following the central axis of the longest tongue (flow line) (see Fig. 5). However, in Western Tungnahryggsjökull, the retreat or advance was measured along different sectors of the front, given its greater complexity (uneven debris cover). Lastly, with the aim of comparing the retreat between the glaciers, average rates of advance and retreat were estimated for the periods between the different dates under analysis. 


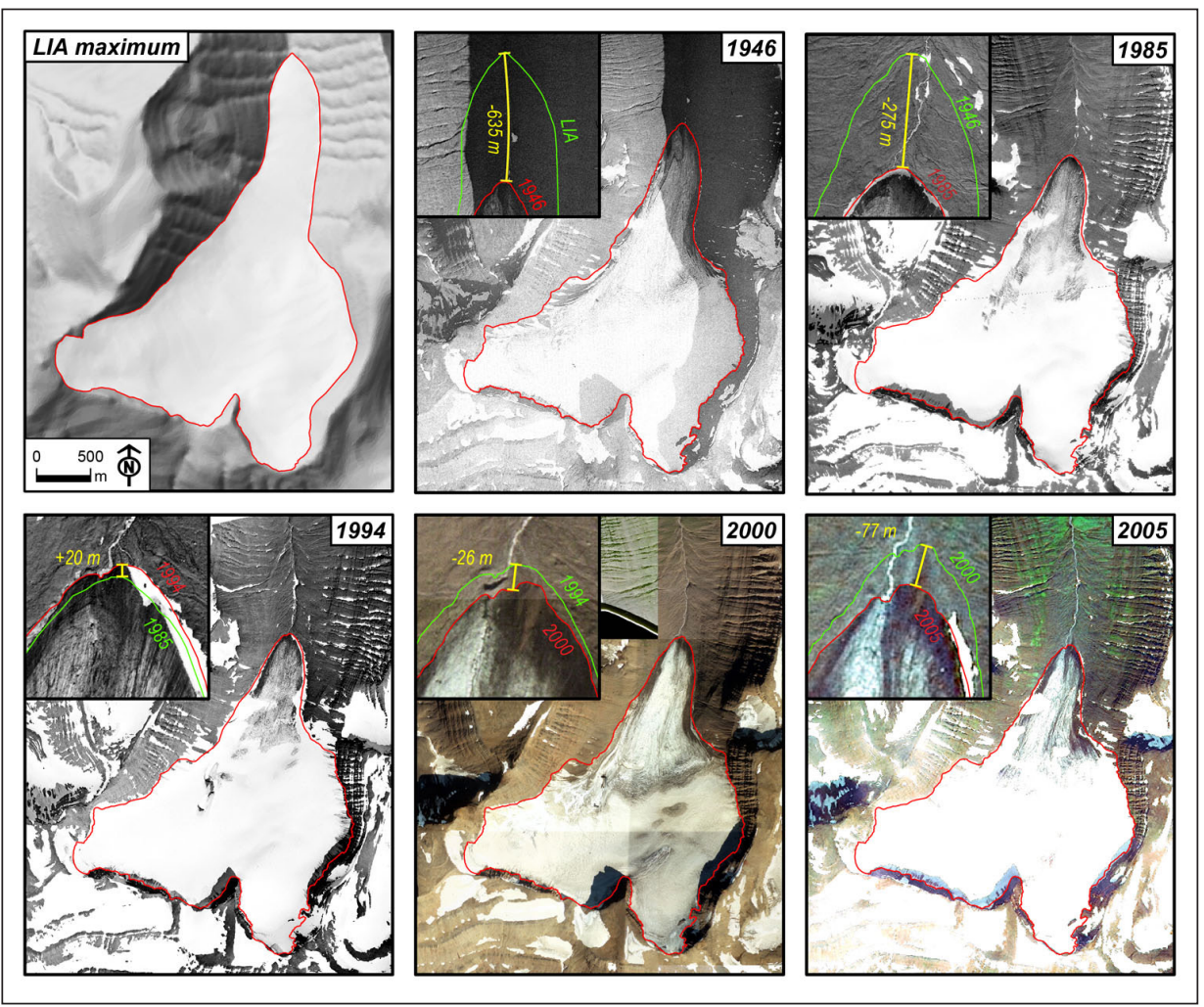

Figure 5. Example of glacier outline mapping of Gljúfurárjökull at different dates, based on visual inspection of georeferenced aerial photos. The yellow line and number refer to the measurement of the snout retreat/advance along the flow line. Green and red numbers correspond to the dates for which the glacier outlines were drawn.

\subsection{Calculation of areas and volumes}

The areas of the glaciers were calculated in 2D using the "Calculate Geometry" (Area) function in ArcMap. The figures obtained were used to estimate the ice volumes through the area-volume scaling (AVS) approach according to Bahr et al. (1997). This method was chosen due to its convenience in calculating volumes when radio echosounding surveys are not available to estimate ice thicknesses, as is the case here. AVS is based on the existence of a proportional and exponential relation (1) between the area of the glaciers $(S)$ and their volume $(V)$.

$$
V \propto S^{\gamma}
$$

where $V$ and $S$ are expressed in $\mathrm{km}^{3}$ and $\mathrm{km}^{2}$, respectively.

This relationship was demonstrated by statistical regression for 144 glaciers worldwide with reliable radio echo-sounding, excluding ice sheet and ice cap glaciers, with a regression coefficient of 1.36 (which is in turn $\gamma$ ) and squared correlation coefficient 
$\mathrm{R}^{2}=0.99$ (Meier and Bahr, 1996; Bahr et al., 1997). This approach is based, on the one hand, on the proportionality between a series of geometric parameters (volume as a function of area and average thickness, area as a function of length and width, width as a function of thickness) and its association with other parameters affecting the dynamics of the ice (slope, lateral drag and mass balance). The exponential relation between area and volume is scaled by a $\gamma$ exponent (1) as a dimensionless quantity describing the interaction of the abovementioned parameters (2).

$$
y=1+\frac{1+m+n(f+r)}{(q+1)(n+2)}
$$

As a preliminary approximation to the volumes of Gljúfurárjökull and Tungnahryggsjökull, the $\gamma$ exponent was calibrated in the estimates for the glaciers under study according to the considerations of Bahr et al. (1997). The width $(q)$ of the glaciers was expressed as $q=0.6$, which in turn represents an inventory of glaciers in Eurasia and the Alps (Bahr, 1997). The slope ( $r$ ) was assumed to be steep $(r=0)$ because they are cirque glaciers, as opposed to the gentle slopes characteristic of large ice masses $(r=1)$. Regarding the lateral drag of the ice $(f)$, depending on the values chosen in the other variables (width, slope and mass balance), $f=0$ was assumed because it approximates $\gamma \approx 1.36$ observed by statistical regression between area and volume (Meier and Bahr, 1996; Bahr et al., 1997). Mass balance was expressed as $m=2$, agreeing with the average accumulation area ratio (AAR) obtained from Bahr's inventory of glaciers in Eurasia and the Alps (1997). Lastly, for the flow parameter $(n), n=3$ was assumed as the typical ice value versus $n \rightarrow \infty$ (assuming perfect plasticity for ice sheets), according to Glenn's flow law (1958). As a result of the scaling of the above parameters, $\gamma=1.375$. We applied a constant of proportionality $(c)$ of $c=0.2055 \mathrm{~m}^{3-2 \gamma}$ for mountain glaciers (Chen and Ohmura, 1990) to the scaling of the relation expressed in (3).

$V \propto c S^{\gamma}$

It is possible to obtain an estimate of the uncertainty associated with the use of theoretical scaling $(\gamma=1.375)$ by comparing it with the results obtained with $\gamma=1.36$, which is considered empirical. A more detailed explanation and discussion of the physical fundamentals of AVS and the mathematical treatment and individual scaling of the variables can be found in Bahr et al. (1997) and Bahr et al. (2015).

\subsection{Calculation of glacier Equilibrium-Line Altitude (ELA), glacier reconstruction, application of glacier-climate models and paleoclimate reconstruction}

ELA was selected as another indicator of climate effect on glaciers (Nesje, 1992) because it marks: 1) the average altitude of a glacier's surface where the specific mass balance equals zero (Cogley et al., 2011); 2) climatic conditions sufficient for glacier survival (Ohmura et al., 1992); and because of the potential for inferring climate changes from fluctuations in its altitude (Pellitero et al., 2015), given its close connection with the local climate (Benn and Lehmkuhl, 2000). In order to 
observe the impact of climate change on the glaciers selected, ELAs were calculated for all the available dates since the LIA maximum, using the Accumulation Area Ratio (AAR, Brückner, 1886, 1887) and Area Altitude Balance Ratio (AABR; Osmaston, 2005) methods. Both methods require the glaciers topography, although the only one available was obtained for the whole of Iceland at a scale of 1:20,000 in the year 2000 (National Land Survey of Iceland, 2015). For the LIA, the topography was reconstructed from the lateral and frontal moraines, used as geomorphological evidence of the thickness and extent of the glaciers. The cartographic approach (Sissons, 1974; Pellitero et al., 2015), based on the manual drawing of contour lines, was followed so that these lines would reproduce the topography currently observed in the glaciers, with concave (convex) curves above (below) the ELA, the further the contours were from the ELA, the more concave (convex) they were draw above (below) this level. Because there was no topography for the remaining dates, reconstruction was carried out in the same way for 1946, 1985, 1994 and 2005, although only for the sectors of the tongues where changes were observed (positions that were further forward or behind), while the remainder of the glacier surface was left with the topography of the year 2000. Next, the glaciers DEMs were created for the different dates under analysis based on the interpolation of the contour lines with the ArcGIS "Topo to Raster" tool. Lastly, the ELA was automatically calculated in the ArcMap work environment using the "ELA calculation" toolbox designed by Pellitero et al. (2015), in which a $5 \mathrm{~m}$ contour interval was established. For the AAR method, the 0.67 ratio previously used in Tröllaskagi (Caseldine and Stötter, 1993) was established because its results corresponded to the maximum altitude of the lateral moraines (Stötter, 1990). Finally, for exploratory purposes, the AABR method was used. To our knowledge, it was not tested with Tröllaskagi glaciers until now due to the scarcity of current mass balance studies (e.g. Björnsson, 1971) on these glaciers, so we tentatively used the $1.5 \pm 0.4$ Balance Ratio (BR) proposed for Western Norway glaciers (Rea, 2009).

\subsection{Analysis of climate series, application of glacier-climate models and climatic reconstruction of the LIA}

In parallel with the monitoring of the glaciers, climatic evolution was analyzed based on the records of two weather stations, one located in the city of Akureyri $\left(65^{\circ} 41^{\prime} \mathrm{N} ; 1^{\circ} 06^{\prime} \mathrm{W} ; 23 \mathrm{~m}\right)$ in the interior of Eyjafjörour, and the other on the Öxnadalsheiði mountain road $\left(65^{\circ} 28^{\prime} \mathrm{N} ; 18^{\circ} 41^{\prime} \mathrm{W} ; 540 \mathrm{~m}\right)$ in the south of the Tröllaskagi Peninsula. Although it is located 25 to $35 \mathrm{~km}$ away from the glaciers under study, the Akureyri climate series (Icelandic Meteorological Office, 2017) was taken as a reference of climate change from the LIA to the present day, since it covers a period from 1882 to 2015. The Öxnadalsheiði series (Icelandic Road and Coastal Administration, 2017) only covers 14 years between 2000 and 2014. The processing of the series consisted in applying 5-year running means and identifying cold and warm homogeneous periods by studying the sign of the deviation from the average (Fig. 6), according to Einarsson (1991). The periods identified were characterized according to their average temperatures. 


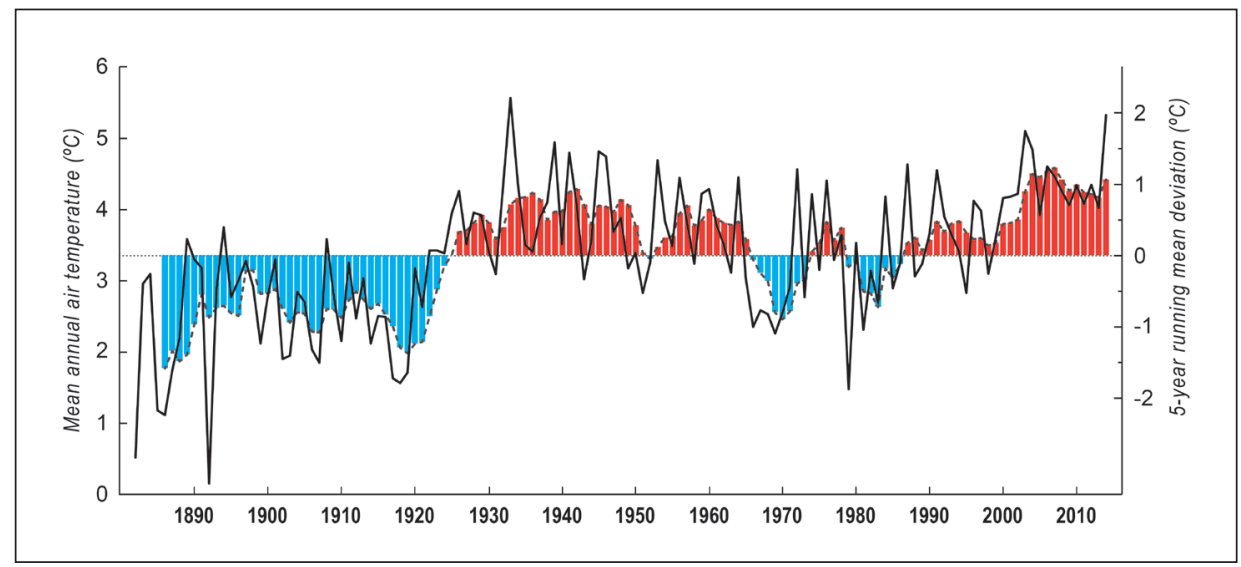

Figure 6. Temperature evolution, 5-year running mean and deviation from the average at Akureyri meteorological station from 1882 to 2014. The thick black line and the grey dashed line correspond to the mean annual air temperature (MAAT) and the 5-year running mean of the MAAT. The red (blue) bars represent the positive (negative) deviations, which correspond to warm (cold) periods.

Subsequently, with the two-fold aim of 1) carrying out a tentative reconstruction of the climate at the end of the LIA and 2) studying the influence of climate variables (temperature and precipitation, as the main controls in ablation and accumulation) at the ELA and their relationship with atmospheric circulation patterns (for a further detailed analysis of this issue, the reader is referred to Fernández-Fernández et al., 2017), three glacier-climate models were applied, based on statistically validated relationships between precipitation and temperature (Liestøl, 1967; Ballantyne, 1989; Ohmura et al., 1992; Braithwaite, 2008) measured at the ELA. Such models make it possible to determine temperature or precipitation if one of the variables is known, generally temperature (Pellitero et al., 2015). The temperature values required by the different models were obtained by extrapolating the average temperatures (annual, ablation season and summer) recorded during each period at the Akureyri station at the mean ELA, assuming the vertical temperature gradient obtained from the statistical treatment of the climate series of Akureyri and Öxnadalsheiði for the 2000-2014 (common) period.

The first model is based on an exponential relationship between the mean temperature of the ablation season and the winter accumulation observed by Sutherland (1984) in a set of ten Norwegian maritime glaciers (Liestø1, 1967) and later expressed by Ballantyne (1989) with the mathematical expression (4):

$$
A=0.915 e^{0,339 T} a
$$

where $A$ is winter accumulation (October-April) expressed in m water equivalents; and $T_{a}$ is the average temperature of the ablation season (May-September), expressed in ${ }^{\circ} \mathrm{C}$. 
The second model was established by Ohmura et al. (1992) based on statistical analysis of the average temperature of the three summer months $\left(T_{s}\right)$ and annual precipitation $(P)$ at the ELA of a set of 70 glaciers worldwide with mass balance monitoring. The statistical analysis of both variables characterized the climate of the ELA with the quadratic equation (5):

$$
P=645+296 T_{s}+9 T_{s}^{2}
$$

where $P$ is the annual total precipitation (the sum of winter mass balance and summer precipitation) expressed in $\mathrm{mm}$; and $T$ is the average temperature of the three summer months (June, July and August) expressed in ${ }^{\circ} \mathrm{C}$. The standard error associated with this model is $200 \mathrm{~mm}$; the variation of $1{ }^{\circ} \mathrm{C}$ is equivalent of $350 \mathrm{~mm}$.

Lastly, we tested the degree-day model (Brugger, 2006; Braithwaite, 2008), based on the proportionality between melting snow/ice at the ELA (ablation) and the summation of positive temperatures (degree-day sum). This proportionality is expressed by the degree-day factor $(d d f)$ resulting from the quotient of the two variables. The use of this third method to estimate precipitation is justified by the definition of ELA, in which the calculation of ablation is equivalent to the calculation of accumulation; in other words, it enables us to know the accumulation necessary to make up for the melt. However, depending on the amount of summer precipitation, total annual rainfall is between the winter balance and the sum of the winter balance and the summer precipitation (Ohmura et al., 1992). Therefore, Braithwaite (2008), based on the data of Ohmura et al. (1992), suggests the use of a $d d f$ between $3.5 \pm 1.4$ and $4.6 \pm 1.4$ day $^{-1}{ }^{\circ} \mathrm{C}^{-1}$, representing low and high accumulations. Nevertheless, in order to facilitate calculation and for exploratory purposes, we used the average $d d f$ value $4.1 \pm 1.5$ day $^{-1}{ }^{\circ} \mathrm{C}^{-1}$ previously used in paleoclimate reconstructions (see Hughes et al., 2010). The application of this model requires knowing the average temperature of each day of the year, which was achieved by simulating in a programmed Excel spreadsheet its distribution throughout the year through a sinusoidal function (6) around the MAAT extrapolated at ELA (Fig. 7):

$$
T_{d}=A \sin \left(\frac{2 \pi d}{\lambda}-\emptyset\right)+M A T T
$$

where $T_{d}$ is the average daily temperature; $A$ is the amplitude (half of the annual thermal range), $d$ is the Julian date (1-365), $\lambda$ is the modelling period (1 year, 365 days), $\Phi$ is the phase angle (1.93 rad so that January is the coldest month), and MAAT is the average annual temperature. 


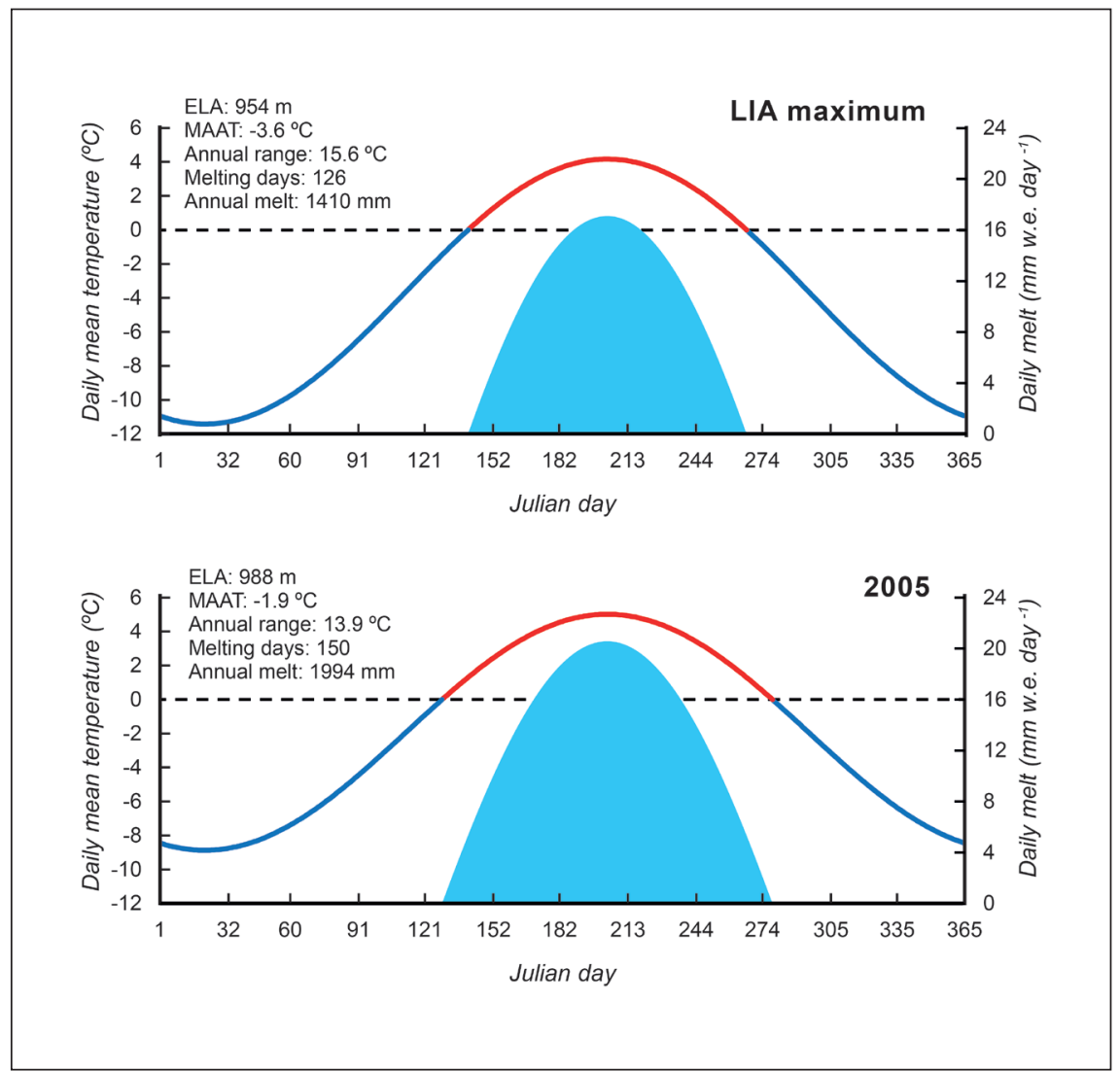

Figure 7. Example of the application of the degree-day model at the ELA of Gljufurárjökull in the LIA maximum and 2005. The red (blue) line corresponds to the temperatures above (below) the freezing point. The blue polygon is the modeled distribution of the daily melt throughout the year. The melting days fairly match to the ablation season from May to September. Note the different annual temperature range, annual melting and the melting days in the two dates.

\section{Results of the application of the methods on the Tröllaskagi glaciers}

\subsection{Evolution of the glacier fronts}

The magnitude of variations in the geometry of the glaciers studied since the LIA did not require precise georeferencing using the photogrammetric restitution techniques (appropriate for researching the movements of rock glaciers or debriscovered glaciers, e.g. Tanarro et al., 2017). The rectification of aerial photographs in a GIS environment was sufficient to record the general retreat of the glaciers since the LIA (1.3 km on average), of which $80 \%$ occurred before 1946. In 1946 the glacier fronts were located approximately 600 to $1500 \mathrm{~m}$ from their positions during the LIA (Table 2). Photogram rectification enabled us to detect advances and retreats 
of smaller magnitudes; in fact, circa 1985 the glacier fronts had clearly retreated compared to the 1946 position, although these figures were not comparable to those of the first half of the 20th century, between 60 and more than $270 \mathrm{~m}$ (Table 2). The trend was reversed in 1994, when Gljúfurárjökull showed a $20 \mathrm{~m}$ advance compared to 1985 . This trend was not as clear at Tungnahryggsjökull, which retreated $26 \mathrm{~m}$ at the apex of the front and had uneven sectors of retreat $(20-40 \mathrm{~m})$ and advance $(20$ $60 \mathrm{~m}$ ). In 2000 and 2005 the glacier tongues retreated again 17 to $93 \mathrm{~m}$ (Table 2) until they recorded the smallest extent. The measurements taken with GIS, even in the lower figures, were quite far from the RMS errors derived from georeferencing through "Adjust" transformation (Table 1).

Table 2. Changes of the glacier snout position from the 'Little Ice Age'(LIA) measured in the GIS over the georeferenced aerial photos.

\begin{tabular}{lcccccc}
\hline Snout position changes $(\boldsymbol{m})$ & \multicolumn{7}{c}{} \\
\hline Glacier & LIA-1946 & $1946-1985$ & $1985-1994$ & $1994-2000$ & $2000-2005$ & A LIA-2005 \\
\hline Gljúfurárjökull & -635 & -275 & +20 & -26 & -77 & -993 \\
Tungnahryggsjökull (W) & -1524 & -60 & -26 & -93 & -32 & -1735 \\
Tungnahryggsjökull (E) & -1027 & -271 & - & - & -17 & -1315 \\
Average & -1062 & -202 & - & - & -42 & -1348 \\
\hline Advance/retreat rate (m $\left.\boldsymbol{y r}^{-1}\right)$ & & & & & & \\
\hline Glacier & LIA-1946 & $1946-1985$ & $1985-1994$ & $1994-2000$ & $2000-2005$ & A LIA-2005 \\
\hline Gljúfurárjökull & -13.2 & -7.1 & +2.2 & -4.3 & -15.4 & -9.3 \\
Tungnahryggsjökull (W) & -19.5 & -1.5 & -2.9 & -15.5 & -6.4 & -12.7 \\
Tungnahryggsjökull (E) & -13.2 & -6.9 & - & - & -3.4 & -9.3 \\
Average & -15.3 & -5.2 & - & - & -8.4 & -10.4 \\
\hline
\end{tabular}

\subsection{Evolution of areas and volumes}

Measurement of glacier areas and calculations of the variation in volumes throughout different dates have confirmed the tendency of the glaciers to retreat/ shrink since the LIA maximum. The glaciers have reduced in extent since the LIA, in parallel with a retreat of their fronts. Area calculations show a reduction of $25 \%$ between the LIA and 2005, with the largest losses again clustered before 1946 (Table 3 ); the same is true regarding retreat, although the magnitude of the changes in front positions and areas is only comparable in relative terms: $80 \%$ of the total retreat and $72 \%$ of the total reduction in area between the LIA maximum and 2005 had occurred by 1946. Area increases were only observed in 1994 in the Gljúfurárjökull and Western Tungnahryggsjökull glaciers, as well as in 2000 in Eastern Tungnahryggsjökull; at the following dates there was progressive reduction, although less marked than in the first half of the 20th century (Table 3). Volume calculations also demonstrated changes in the glaciers since the LIA, with a general reduction trend similar to that of the areas -except for an increase in volume during the 1985-1994 period-although 
in this case the reduction from the LIA to 2005 was more pronounced, 33\% (Table 3 ), as well as in the remaining periods.

Table 3. Glacier surfaces/volume changes from the 'Little Ice Age'(LIA) measured by applying the ArcGIS "Calculate geometry" function and calculated through the area-volume scaling approach.

\begin{tabular}{|c|c|c|c|c|c|c|c|}
\hline \multicolumn{8}{|l|}{$\operatorname{Area}\left(\mathrm{km}^{2}\right)$} \\
\hline Glacier & LIA & 1946 & 1985 & 1994 & 2000 & 2005 & $\triangle L I A-2005$ \\
\hline Gljúfurárjökull & 4.372 & 3.540 & 3.407 & 3.413 & 3.384 & 3.335 & -1.038 \\
\hline Tungnahryggsjökull (W) & 8.735 & 6.939 & 6.689 & 6.700 & 6.604 & 6.512 & -2.222 \\
\hline Tungnahryggsjökull (E) & 5.348 & 4.532 & 4.035 & - & 4.054 & 3.940 & -1.408 \\
\hline Total & 18.455 & 15.011 & 14.131 & - & 14.041 & 13.787 & -4.668 \\
\hline \multicolumn{8}{|l|}{ Area increase/decrease (\%) } \\
\hline Glacier & $L I A$ & LIA-1946 & 1946-1985 & 1985-1994 & $1994-2000$ & $2000-2005$ & $\triangle L I A-2005$ \\
\hline Gljúfurárjökull & - & -19.0 & -3.7 & +0.2 & -0.9 & -1.5 & -23.7 \\
\hline Tungnahryggsjökull (W) & - & -20.6 & -3.6 & +0.2 & -1.4 & -1.4 & -25.4 \\
\hline Tungnahryggsjökull (E) & - & -15.3 & -11.0 & - & - & -2.8 & -26.3 \\
\hline Total & - & -18.7 & -5.9 & - & - & -1.8 & -25.3 \\
\hline \multicolumn{8}{|l|}{ Volume $\left(\mathrm{km}^{3}\right)$} \\
\hline Glacier & LIA & 1946 & 1985 & 1994 & 2000 & 2005 & $\triangle L I A-2005$ \\
\hline Gljúfurárjökull & 0.278 & 0.208 & 0.197 & 0.198 & 0.195 & 0.191 & -0.086 \\
\hline Tungnahryggsjökull (W) & 0.720 & 0.524 & 0.498 & 0.500 & 0.490 & 0.481 & -0.239 \\
\hline Tungnahryggsjökull (E) & 0.367 & 0.292 & 0.249 & - & 0.250 & 0.241 & -0.126 \\
\hline Total & 1.364 & 1.024 & 0.944 & - & 0.936 & 0.913 & -0.451 \\
\hline \multicolumn{8}{|c|}{ Volume increase/decrease (\%) } \\
\hline Glacier & $L I A$ & LIA-1946 & 1946-1985 & 1985-1994 & $1994-2000$ & $2000-2005$ & $\triangle L I A-2005$ \\
\hline Gljúfurárjökull & - & -25.2 & -5.1 & +0.2 & -1.2 & -2.0 & -31.1 \\
\hline Tungnahryggsjökull (W) & - & -27.1 & -4.9 & +0.2 & -2.0 & -1.9 & -33.2 \\
\hline Tungnahryggsjökull (E) & - & -20.4 & -14.8 & - & - & -3.8 & -34.3 \\
\hline Total & - & -24.9 & -7.8 & - & - & -2.4 & -33.1 \\
\hline
\end{tabular}

\subsection{ELA calculation, analysis of climate series and application of glacier-climate models}

The use of the ELA as another indicator has satisfactorily justified the evolution of the glaciers. Since the LIA the ELA rose between 40 and $50 \mathrm{~m}$ depending on whether the AAR $(0.67)$ or the AABR $(1.5 \pm 0.4)$ method was considered (Table 4). The results obtained from both methods are quite similar and consistent with each other, and the largest difference (Western Tungnahryggsjökull since 1946) is only +11 in favor of AABR. As regards general evolution, the most significant figures are the largest ELA increase (on average $\sim 30 \mathrm{~m}$ ) in the period prior to 1946 (Table 4), the slight decrease (2-3 m) between 1985 and 1994 and the increase since 2000 (on average $\sim 3 \mathrm{~m}$ ). 
The analysis of the Akureyri and Öxnadalsheiði climate series indicates a clearly warming climate trend (Akureyri: function $y=0.0093 x+7.815 ; \mathrm{R}^{2}=0.1211$ ), more marked since 2003 (Fig. 6). In the case of Akureyri, the average annual temperature for the $1882-2015$ period was $3.4^{\circ} \mathrm{C}$. By studying its evolution as running means and the sign of the deviation from the mean, a number of periods with negative deviations (cold) and positive deviations (warm) were identified (Table 5). The cold periods recorded are 1882-1924, 1951-1955 and 1979-1986, of which the first is representative of the thermal regime at the end of the LIA $\left(\mathrm{MAAT}=2.5^{\circ} \mathrm{C}\right.$ ) while the other two represent minor cooling $\left(\mathrm{MAAT}=[2.8,2.9]^{\circ} \mathrm{C}\right)$ with shorter durations. The warm periods were 1925-1950, 1956-1965, 1974-1978, 1987-2002 and 2003-2014. The most significant of these are the first and especially the last period because they showed the highest MAATs in the series, reaching over 3.9 and $4.4^{\circ} \mathrm{C}$ respectively (Table 6). The difference between the coldest and the warmest periods indicates a $1.5-1.9^{\circ} \mathrm{C}$ warming. From the statistical treatment of the two climate series for the 2000-2014 common period, a vertical temperature gradient of $0.67^{\circ} \mathrm{C} 100 \mathrm{~m}^{-1}$ was obtained.

Table 4. ELAs of the Gljúfurárjökull and Tungnahryggsjökull glaciers obtained from the application of the AAR and AABR methods.

\begin{tabular}{|c|c|c|c|c|c|c|c|}
\hline \multicolumn{8}{|l|}{$\overline{E L A-A A R}(0.67)$ ( $m$ a.s.l.) } \\
\hline Glaciers & LIA & 1946 & 1985 & 1994 & 2000 & 2005 & $\triangle L I A-2005$ \\
\hline Gljúfurárjökull & 954 & 974 & 985 & 982 & 984 & 988 & +34 \\
\hline Tungnahryggsjökull (W) & 1046 & 1082 & 1092 & 1090 & 1091 & 1094 & +48 \\
\hline Tungnahryggsjökull (E) & 1029 & 1061 & 1069 & - & 1071 & 1073 & +44 \\
\hline Average & 1010 & 1039 & 1049 & - & 1049 & 1052 & +42 \\
\hline \multicolumn{8}{|c|}{ ELA-AABR (1.5 \pm 0.4$)$ ( $m$ a.s.l.) } \\
\hline Glaciers & $L I A$ & 1946 & 1985 & 1994 & 2000 & 2005 & $\triangle L I A-2005$ \\
\hline Gljúfurárjökull & $960 \pm 20$ & $975 \pm 15$ & $986 \pm 20$ & $988 \pm 15$ & $990 \pm 15 \quad 9$ & $994+15 /-10$ & 34 \\
\hline Tungnahryggsjökull (W) & $1047+20 /-15$ & $1093 \pm 10$ & $1103 \pm 10$ & $1101 \pm 10$ & $1102+10 /-5$ & $1105 \pm 10$ & 58 \\
\hline Tungnahryggsjökull (E) & $1020+20 /-15$ & $1062 \pm 15$ & $1075 \pm 10$ & - & $1072+15 /-10$ & $1079 \pm 10$ & 59 \\
\hline Average & $1009 \pm 36$ & $1043 \pm 50$ & $1055 \pm 50$ & - & $1055 \pm 47$ & $1059 \pm 47$ & 50 \\
\hline
\end{tabular}

Glacier-climate models have proved to be another reliable indicator of climate change, since their testing highlights the occurrence of successive changes in the climate of the ELA (seen as the average for the three glaciers) since the LIA throughout the different periods considered; this is coherent with those previously observed regarding the dynamics of the fronts, the ELAs and the climate series, with evident warming of between 1.2 and $1.7^{\circ} \mathrm{C}$ (Table 6). The three models also coincide as to a reduction in precipitation during the LIA maximum; a generalized increase since then is confirmed, with figures varying from 400-500 to over $700 \mathrm{~mm}$ (Table 6) if compared to the estimated values of the LIA, which means that a higher amount of accumulation is required to make up for the melt. 
Table 5. Cold and warm periods identified at the Akureyri meteorological station. Mean deviation refers to the 5-year running mean of the MAAT.

\begin{tabular}{llccccc}
\hline \multirow{2}{*}{\begin{tabular}{l} 
Period \\
\cline { 3 - 6 }
\end{tabular}} & Type & $\begin{array}{c}\text { Mir temperature }\left({ }^{\circ} \mathbf{C}\right) \\
\text { deviation }\end{array}$ & Annual & $\begin{array}{c}\text { May-to- } \\
\text { September }\end{array}$ & $\begin{array}{c}\text { June-July- } \\
\text { August }\end{array}$ & $\begin{array}{c}\text { Annual } \\
\text { range }\end{array}$ \\
\hline $1882-1924$ & Coldest & -0.84 & 2.52 & 7.86 & 9.41 & 15.59 \\
$1925-1950$ & Warm & +0.60 & 3.95 & 9.05 & 10.38 & 14.80 \\
$1951-1955$ & Cold & +0.23 & 3.62 & 8.60 & 9.96 & 14.71 \\
$1956-1965$ & Warm & +0.50 & 3.79 & 8.38 & 9.52 & 14.56 \\
$1966-1973$ & Cold & -0.48 & 2.81 & 8.12 & 9.47 & 15.44 \\
$1974-1978$ & Warm & +0.26 & 3.61 & 8.73 & 10.31 & 15.75 \\
$1979-1986$ & Cold & -0.32 & 2.93 & 7.91 & 9.85 & 14.84 \\
$1987-2002$ & Warm & +0.31 & 3.77 & 8.95 & 10.27 & 14.71 \\
$2003-2014$ & Warmest & +1.01 & 4.44 & 9.32 & 10.92 & 13.89 \\
\hline
\end{tabular}

Table 6. Temperature and precipitation predicted at the mean ELA from the lapse rate and the three glacier-climatic models. Note that annual precipitation is considered for the Ohmura et al. (1992) and the degree-day; the Ballantyne (1989) model considers winter accumulation. The global data of 1994 are not provided since aerial photos, glacier extent and ELA are not available for the three glaciers.

\begin{tabular}{|c|c|c|c|c|c|c|}
\hline Period / model & $L I A$ & 1946 & 1985 & 2000 & 2005 & $\triangle L I A-2005$ \\
\hline \multicolumn{7}{|c|}{ Mean air temperature $\left({ }^{\circ} \mathrm{C}\right)$} \\
\hline May-to-September & 1.4 & 2.4 & 1.1 & 2.2 & 2.5 & +1.2 \\
\hline June-July-August & 2.9 & 3.7 & 3.1 & 3.5 & 4.1 & +1.2 \\
\hline \multirow[t]{2}{*}{ Annual } & -4.0 & -2.8 & -3.8 & -3.0 & -2.4 & +1.7 \\
\hline & \multicolumn{6}{|c|}{ Precipitation ( $m m$ water equivalent) } \\
\hline Ballantyne (1989) & 1445 & 2029 & 1344 & 1913 & 2159 & +714 \\
\hline Ohmura et al. (1992) & 1578 & 1854 & 1641 & 1791 & 2022 & +444 \\
\hline Degree-day (Braithwaite, 2008) & 1223 & 1713 & 1148 & 1552 & 1741 & +518 \\
\hline
\end{tabular}

\section{Discussion}

The validity of the results obtained and of the methodological proposal is supported by a correct evaluation of the techniques applied, which is developed and contextualized in the aspects of geometric variations (area and position of the front), volume estimates, reconstruction of paleoglaciers, calculation of ELAs and application of glacier-climate models, within the framework of previous studies with similar methodologies.

\subsection{Variations in the glacier geometry: area and position of the front}

Photointerpretation of geomorphological features (frontal and lateral moraines, ground color changes in the foreland) allowed us to clearly reconstruct the geometry of the glaciers under study during the LIA maximum, as previously demonstrated in Iceland 
(Bradwell et al., 2006; Hannesdóttir et al., 2015) and in other areas (e.g. Colucci and Žebre, 2016), which, in addition, even makes it possible to reconstruct year-by-year front positions from complete sequences of annual moraines (Bradwell et al., 2004, Chandler et al., 2016). The study of the glacial evolution since 1946, based on the manual delineation of glacial outlines from visual inspection of aerial photographs and satellite images, can be considered a valid procedure endorsed in the literature by satisfactory results with debris-free glaciers (e.g. Bradwell et al.,2006, 2013; Koblet et al., 2010; Thompson et al., 2011) as well as debris-covered glaciers (e.g. D'Agata and Zanutta, 2007; Diolaiuti et al., 2009), although it must be noted that the highest levels of precision of these studies were achieved by photogrammetric restitution. Remote sensing -in some cases aided by the application of band ratios or thresholding of ratio images- also provided good results in studies of changes in glacier areas and lengths (e.g. Bahuguna et al., 2007; Kaldybayev et al., 2016; Qureshi et al., 2017).

In this study, measurements of front position changes and calculations of retreat/ advance ratios were carried out on the flow line. With a slight modification, Koblet et al. (2010) measured the length of the tongues considering the average length of the main line (flow line) and other parallel and equidistant additional lines. Changes in the position of the fronts were also analyzed in other studies by crest-to-crest measurements along transects over an annual moraine sequence (Bradwell et al., 2013; Chandler et al., 2016). Although a good statistical correlation between retreat/advance ratios and summer temperature has been found in the literature (e.g. Kirkbride, 2002; Bradwell et al., 2004), it should be noted that variations of the front are not in themselves an indicator of climate change, since they depend not only on mass balance but also on ice speed as it flows from the accumulation zone to the ablation zone (Gabbud et al., 2016). This issue justifies the need to seek other complementary indicators.

\subsection{Volume calculation}

The area-volume scaling approach (Bahr et al., 1997, 2015) used in this study is also widely accepted when estimating glacier volumes at the present time (e.g. Hughes, 2009b), studying their evolution over time (e.g. Chen and Ohmura, 1990; Colucci and Žebre, 2016; Fernández-Fernández et al.,2017) and modelling glacier volume projections in their response to climate change (e.g. Van de Wal and Wild, 2001; Radić et al., 2007; Möller and Schneider, 2010; Adhikari and Marshall, 2012). Some modifications of the implementation of the method derive from different area-volume scaling relationships: for instance, Hughes $(2008,2009 b)$ chose the empirical area-volume relationship of Chen and Ohmura (1990) based on 63 mountain glaciers $(\gamma=1.357)$, while we use the theoretical $\gamma=1.375$. Our application of AVS without any adjustment of $\gamma=1.375$ can be taken as valid according to Bahr et al. (2015) because adjustments to this recommended value are possible but improbable, given that width, mass balance and AAR closures lead to the same result. In any case, the theoretical and the empirically derived values of $\gamma$ are very close each other. Even though this method has been applied to individual glaciers (e.g. Hughes, 2009b; Fernández-Fernández et al., 2017), it should be noted that maximum reliability of the calculations is obtained when applied to a large number of 
glaciers of different sizes and types. So when AVS is applied individually to a glacier without establishing its $c$ it entails considerable uncertainty - up to $34 \%$ if the mean value of $c=0.034 \mathrm{~km}^{3-2 \gamma}$ (Bahr, 1997) is used (Bahr et al., 2015). Moreover, it should be borne in mind that the volume of a non-steady-state glacier is $20 \%$ smaller than the one calculated from the AVS (Van de Wal and Wild, 2001). Because of these limitations, we should treat our results with care, since no other measurements that are more accurate exist for the glaciers studied.

\subsection{Paleoglacier reconstruction}

The manual reconstruction of glacier topography ("hand-drawn" contours) from geomorphological evidence (or the geometry of the front visible in aerial photographs) tested in the glaciers under study can be considered a valid alternative compared with numerical physical-based models (e.g. Schilling and Hollin, 1981; Benn and Hulton, 2010; Pellitero et al., 2016) when there are no other DEMs of the surface of the glaciers, because it approximates the probable three-dimensional shape (Carr and Coleman, 2007). Many examples of its successful application found in the literature (e.g. Sissons, 1974; Sutherland, 1984; Ballantyne, 1989; Dahl and Nesje, 1992). Dahl and Nesje (1992) stated that the error resulting from the reconstruction of the contour lines is randomly distributed over the surface of the glacier, and considered that it does not introduce large deviations with regard to representative conditions.

\subsection{Calculation of ELAs and application of glacier-climate models}

Like in this study, ELA has been successfully used in other areas of study as an indicator of climate change (e.g. Dahl and Nesje, 1992; Stillas et al., 2016; Sagredo et $a l ., 2017)$. In some occasions, however, the snowline obtained by visual inspection of satellite images (e.g. Rabatel et al., 2012; Veettil et al., 2017 and references therein) has likewise been used. Using an AAR of 0.67 based on previous experiments (Caseldine and Stötter, 1993) can be considered appropriate due to its proximity and partial overlap with the $0.64 \pm 0.04$ ratio proposed by Kern and László (2010) for small glaciers over $4 \mathrm{~km}^{2}$, as is the case of those under study. Our calculated ELAs can be considered reliable indicators of climate change due to the consistency between their fluctuations and the climate variability observed in the period analyzed. The innovative testing of the AABR method in Tröllaskagi in this study with a ratio of $1.5 \pm 0.4$ seems to confirm the validity of the ELAs obtained via the AAR method. In other studies, ELAs have been inferred from meteorological records (Lie et al., 2003); this enables the estimation of the current ELA in non-glaciated areas, as well as an assessment of the connection between glaciers and climate variability (e.g. Styllas et al., 2016 in Mount Olympus, Greece). In other studies, analysis of the ELA spatial pattern (e.g. Caseldine and Stötter, 1993) and its gradient have helped to infer precipitation gradients (e.g. Chandler and Lukas, 2017 and references therein), the influence of the relief on past climates (SantosGonzález et al., 2013) and even past atmospheric circulation patterns and weather types (e.g. Ballantyne, 1989). 
The study of climate evolution based on glacier-climate models that relate temperature and precipitation (accumulation) at the ELA can be considered a valid technique when analyzing the impact of climate change, as it makes it possible to know the climatic conditions that promote or hinder glacier survival. In the literature there are numerous examples of the successful application of this type of method. Fernández-Fernández et al. (2017) used the three methods proposed in this paper in the Tröllaskagi Peninsula, with results that were consistent among themselves when reconstructing precipitation during the LIA and its subsequent evolution. Ballantyne (1989), Dahl and Nesje (1992), Caseldine and Stötter (1993) approached paleoclimate reconstructions in Scotland, Western Norway and Tröllaskagi (Northern Iceland) respectively with the glacier-climate model designed for Norwegian maritime glaciers, which made it possible to estimate vertical precipitation gradients as well as to infer changes in atmospheric circulation. Likewise, one can find examples of applications of Ohmura et al. (1992) model in paleoclimate reconstructions in Wales (Hughes, 2009a), in the Pindus Mountains of Greece (Hughes et al., 2006), in South Africa (Mills et al., 2012) and in the Cantabrian Mountains of northern Spain (Pellitero, 2013; Rodríguez-Rodríguez et al., 2016). Carr et al. (2010) suggested the possibility of eliminating summer precipitation from the Ohmura et al. (1992) model, which facilitates comparison of the results obtained from the latter two methods as regards winter accumulation. The understanding of topographic conditions that favor snow accumulation and glacier survival has improved by mapping potential avalanche/ snowblow areas and calculating the so-called snowblow and avalanche ratios (e.g. Sissons and Sutherland, 1976; Sutherland, 1984; Hughes, 2008, 2009b; Mills et al., 2012; Chandler and Lukas, 2017). With this approach it is particularly useful to estimate the proportion of accumulation resulting from avalanches or redistribution by wind. Finally, simplified versions of the degree-day model such as the one used in the present study with an average $d d f$ of $4.1 \pm 1.5 \mathrm{~mm}$ day $^{-1}{ }^{\circ} \mathrm{C}^{-1}$ have also been successfully applied, both in paleoclimate reconstruction and in estimates of the accumulation needed in glaciers to make up for ablation (e.g. Hughes, 2008, 2009b; Hughes and Braithwaite, 2008; Hughes, et al., 2010). On the other hand, Brugger (2006) improved the estimates of the degree-day model applied to paleoclimate reconstruction in the Sawatch Range (Colorado, United States) by simulating the evolution of snowfall throughout the year, alternately using different $d d f$ for ice $\left(8.0 \pm 1.0 \mathrm{~mm} \mathrm{day}^{-1}{ }^{\circ} \mathrm{C}^{-1}\right)$ and snow $(4.0 \pm 1.0$ $\mathrm{mm}$ day ${ }^{-1}{ }^{\circ} \mathrm{C}^{-1}$ ) depending on whether the melt rate modelled by the degree-day model exceeds snow accumulation. When comparing the results derived from the Ohmura et al. (1992) and degree-day models, it should be noted that their discrepancy depends on summer temperatures and the annual temperature range, which influence the amount of liquid or solid precipitation (Hughes, 2009a).

\section{Conclusions}

1. We propose a methodology for using glaciers as indicators of climate change from different points of view that take into account variations in front positions, geometry, volumes, ELAs, the analysis of climatological series and the application of glacier-climate models. 
2. The testing of the methodology proposed in the Gljúfurárjökull and (Western and Eastern) Tungnahryggsjökull glaciers shows that: 1) glaciers lost approximately $25 \%$ of their area and $33 \%$ of their volume, and retreated on average $1.3 \mathrm{~km}$ between the LIA maximum and 2005 as a consequence of the $1.5-1.9^{\circ} \mathrm{C}$ warming; 2) the LIA climate was less humid, and since then precipitation has increased by 28 to $49 \%$.

3. The different methods and techniques utilized were compared with those applied in other studies that focused on the relationships between climate oscillations and glacier response, and on paleoclimate reconstruction. Testing the methods that form the methodological proposal in diverse areas and time scales encourages their application in contrasting areas.

4. The selection of different interrelated climate change indicators improves understanding of the relationships between climate fluctuations and glacier response. This approach is especially useful in the study of the LIA and its subsequent evolution, due to the availability of more accurate and reliable climate records than for earlier times when the only available climate information originates from inferences from other proxies.

\section{Acknowledgements}

This paper was funded by the projects CGL2012-35858 and CGL2015-65813-R (Spanish Ministry of Economy and Competitiveness) and Nils Mobility Program (EEA GRANTS), and with the help of the Research Group of High Mountain Physical Geography (Complutense University of Madrid). José M. Fernández-Fernández received a grant from the FPU program (Spanish Ministry of Education, Culture and Sport; reference FPU14-06150). We specially thank the two anonymous reviewers for their valuable and constructive comments, suggestions and corrections, which improved the earlier version of the manuscript.

\section{References}

Adhikari, S., Marshall, S.J. 2012. Glacier volume-area relation for high-order mechanics and transient glacier states. Geophysical Research Letters 39 (16), L16505. http://doi. org/10.1029/2012GL052712.

Ahlmann, H.W. 1924. Le niveau de glaciation comme fonction de l'accumulation d'humidité sous forme solide. Méthode pour le calcul de l'humidité condensée dans la haute montagne et pour l'étude de la fréquence des glaciers. Geografiska Annaler 6 (3-4), 223-272. http://doi. org/10.2307/519625.

Andrés, N., Tanarro, L.M., Fernández, J.M., Palacios, D. 2016. The origin of glacial alpine landscape in Tröllaskagi Peninsula (North Iceland). Cuadernos de Investigación Geográfica 42 (2), 341-368. http://doi.org/10.18172/cig.2935.

Bahr, D.B. 1997. Global distributions of glacier properties: A stochastic scaling paradigm. Water Resources Research 33 (7), 1669-1679. http://doi.org/10.1029/97WR00824.

Bahr, D.B., Meier, M.F., Peckham, S.D. 1997. The physical basis of glacier volume-area scaling. Journal of Geophysical Research: Solid Earth 102 (B9), 20355-20362. http://doi. org/10.1029/97JB01696. 
Bahr, D.B., Pfeffer, W.T., Kaser, G. 2015. A review of volume-area scaling of glaciers. Reviews of Geophysics 53 (1), 95-140. http://doi.org/10.1002/2014RG000470.

Bahuguna, I.M., Kulkarni, A.V., Nayak, S., Rathore, B.P., Negi, H.S., Mathur, P. 2007. Himalayan glacier retreat using IRS 1C PAN stereo data. International Journal of Remote Sensing 28 (2), 437-442. http://doi.org/10.1080/01431160500486674.

Ballantyne, C.K. 1989. The Loch Lomond Readvance on the Isle of Skye, Scotland: Glacier reconstruction and palaeoclimatic implications. Journal of Quaternary Science 4 (2), 95-108. http://doi.org/10.1002/jqs.3390040201.

Benn, D.I., Hulton, N.R.J. 2010. An Excel ${ }^{\mathrm{TM}}$ spreadsheet program for reconstructing the surface profile of former mountain glaciers and ice caps. Computers and Geosciences 36 (5), 605 610. http://doi.org/10.1016/j.cageo.2009.09.016.n

Benn, D.I., Lehmkuhl, F. 2000. Mass balance and equilibrium-line altitudes of glaciers in highmountain environments. Quaternary International 65-66, 15-29. https://doi.org/10.1016/ S1040-6182(99)00034-8.

Björnsson, H. 1971. Bægisarjökull, North Iceland. Results of glaciological investigations 1967-68. Part I. Mass balance and general meteorology. Jökull 21, 1-23.

Bradwell, T. 2004. Annual moraines and summer temperatures at Lambatungnajökull, Iceland. Arctic, Antarctic, and Alpine Research 36 (4), 502-508. https://doi.org/10.1657/15230430(2004)036[0502:AMASTA]2.0.CO;2.

Bradwell, T., Dugmore, A.J., Sudgen, D.E. 2006. The Little Ice Age glacier maximum in Iceland and the North Atlantic Oscillation: evidence from Lambatungnajökull, southeast Iceland. Boreas 35 (1), 61-80. http://doi.org/10.1111/j.1502-3885.2006.tb01113.x.

Bradwell, T., Sigurđsson, O., Everest, J. 2013. Recent, very rapid retreat of a temperate glacier in SE Iceland. Boreas 42 (4), 959-973. http://doi.org/10.1111/bor.12014.

Braithwaite, R.J. 2008. Temperature and precipitation climate at the equilibrium-line altitude of glaciers expressed by the degree-day factor for melting snow. Journal of Glaciology 54 (186), 437-444. https://doi.org/10.3189/002214308785836968.

Braithwaite, R.J., Raper, S.C.B., Chutko, K. 2006. Accumulation at the equilibrium-line altitude of glaciers inferred from a degree-day model and tested against field observations. Annals of Glaciology 43, 329-334. https://doi.org/10.3189/172756406781812366.

Brückner, E. 1886. Die Hohern Tauern und ihre Eisbedeckung. Zeitschrift des DeutschÖsterreichische Alpenvereins 17, 163-187. http://www.literature.at/viewer.alo?objid= $1026566 \&$ view mode $=$ fullscreen $\&$ rotate $=\&$ scale $=3.33 \&$ page $=173$..

Brückner, E. 1887. Die Höhern der Schneelinie und ihre Bestimmung. Meteorologische Zeitschrift 4, 31-32.

Brugger, K.A. 2006. Late Pleistocene climate inferred from the reconstruction of the Taylor River glacier complex, southern Sawatch Range, Colorado. Geomorphology 75 (3-4), 318-329. http://doi.org/10.1016/j.geomorph.2005.07.020.

Brynjólfsson, S., Schomacker, A., Ingólfsson, Ó., Keiding, J.K. 2015. Cosmogenic ${ }^{36} \mathrm{Cl}$ exposure ages reveal a $9.3 \mathrm{ka}$ BP glacier advance and the Late Weichselian-Early Holocene glacial history of the Drangajökull region, northwest Iceland. Quaternary Science Reviews 126, 140 157. http://doi.org/10.1016/j.quascirev.2015.09.001.

Carr, S., Coleman, C. 2007. An improved technique for the reconstruction of former glacier mass-balance and dynamics. Geomorphology 92 (1-2), 76-90. https://doi.org/10.1016/j. geomorph.2007.02.008.

Carr, S.J., Lukas, S., Mills, S.C. 2010. Glacier reconstruction and mass-balance modelling as a geomorphic and palaeoclimatic tool. Earth Surface Processes and Landforms 35 (9), 11031115. http://doi.org/10.1002/esp.2034. 
Caseldine, C., Stötter, J. 1993. "Little Ice Age" glaciation of Tröllaskagi peninsula, northern Iceland: climatic implications for reconstructed equilibrium line altitudes (ELAs). The Holocene 3 (4), 357-366. https://doi.org/10.1177/095968369300300408.

Caseldine, C.J. 1983. Resurvey of the Margins of Gljúfurárjökull and the Chronology of recent Deglaciation. Jökull 33, 111-118.

Caseldine, C.J. 1985a. The extent of some glaciers in northern Iceland during the Little Ice Age and the nature of recent deglaciation. Geographical Journal 151 (2), 215-227. http://doi. org/10.2307/633535.

Caseldine, C.J. 1985b. Survey of Gljúfurárjökull and features associated with a glacier burst in Gljúfurárdalur, Northern Iceland. Jökull 35, 61-68.

Caseldine, C.J. 1987. Neoglacial glacier variations in northern Iceland: Examples from the Eyjafjörður area.Arctic and Alpine Research 19 (3), 296-304. http://doi.org/10.2307/1551365.

Caseldine, C.J., Cullingofrd, R.A. 1981. Recent Mapping of Gljúfurárjökull and Gljúfurárdalur. Jökull 31, 11-22.

Chandler, B.M.P., Evans, D.J.A., Roberts, D.H. 2016. Recent retreat at a temperate Icelandic glacier in the context of the last $\sim 80$ years of climate change in the North Atlantic region. Arktos 2, 24. https://doi.org/10.1007/s41063-016-0024-1.

Chandler, B.M.P., Lukas, S. 2017. Reconstruction of Loch Lomond Stadial (Younger Dryas) glaciers on Ben More Coigach, north-west Scotland, and implications for reconstructing palaeoclimate using small ice masses. Journal of Quaternary Science 32 (4), 475-492. http:// doi.org/10.1002/jqs.2941.

Chen, J., Ohmura, A. 1990. Estimation of Alpine glacier water resources and their change since the 1870s. In: H. Lang, A. Musy, Hydrology in Mountainous Regions I. IAHS Publication 193, 127-135. http://hydrologie.org/redbooks/a193/iahs_193_0127.pdf.

Church, J.A., Gregory, J.M., Huybrechts, P., Kuhn, M., Lambeck, K., Nhuan, M.T., Qin, D., Woodworth, P.L. 2001. Changes in sea level. In: J.T. Houghton, Y. Ding, D.J. Griggs, M. Noguer, P.J. Van der Linden, X. Dai, K. Maskell, C.A. Johnson (Eds.), Climate Change 2001: The Scientific Basis. Cambridge University Press, Cambridge, pp. 639-693. http:// homepages.vub.ac.be/ phuybrec/pdf/IPCC.Ch11.2001.pdf.

Cogley, J.G., Hock, R., Rasmussen, L.A., Arendt, A.A., Bauder, A., Braithwaite, R.J., Jansson, P., Kaser, G., Möller, M., Nicholson, L., Zemp, M. 2011. Glossary of glacier mass balance and related terms. IHP-VII Technical Documents in Hydrology 86, IACS Contribution 2, UNESCO-IHP, Paris. http://unesdoc.unesco.org/images/0019/001925/192525e.pdf.

Colucci, R.R. 2016. Geomorphic influence on small glacier response to post-Little Ice Age climate warming: Julian Alps, Europe. Earth Surface Processes and Landforms 41 (9), 1227-1240. http://doi.org/10.1002/esp.3908.

Colucci, R.R., Žebre, M. 2016. Late Holocene evolution of glaciers in the southeastern Alps. Journal of Maps 12, 289-299. http://doi.org/10.1080/17445647.2016.1203216.

Crochet, P., Jóhannesson, T., Jónsson, T., Sigurðsson, O., Björnsson, H., Pálsson, F., Barstad, I. 2007. Estimating the spatial distribution of precipitation in Iceland using a linear model of orographic precipitation. Journal of Hydrometeorology 8, 1285-1306. https://doi. org/10.1175/2007JHM795.1.

D'Agata, C., Zanutta, A. 2007. Reconstruction of the recent changes of a debris-covered glacier (Brenva Glacier, Mont Blanc Massif, Italy) using indirect sources: Methods, results and validation. Global and Planetary Change 56 (1-2), 57-68. https://doi.org/10.1016/j. gloplacha.2006.07.021.

Dahl, S.O., Nesje, A. 1992. Paleoclimatic implications based on equilibrium-line altitude depressions of reconstructed Younger Dryas and Holocene cirque glaciers in inner Nordfjord, 
western Norway. Palaeogeography, Palaeoclimatology, Palaeoecology 94, 87-97. https:// doi.org/10.1016/0031-0182(92)90114-K.

Diolaiuti, G., D’Agata, C., Meazza, A., Zanutta, A., Smiraglia, C. 2009. Recent (1975-2003) changes in the Miage debris-covered glacier tongue (Mont Blanc, Italy) from analysis of aerial photos and maps. Geografia Fisica e Dinamica Quaternaria 32 (1), 117-127. http:// hdl.handle.net/2434/152059.

Einarsson, M.A.1991. Temperature conditions in Iceland 1901-1990. Jökull 41, 1-20. https://www researchgate.net/publication/291794533_Temperature_conditions_in_Iceland_1901-1990.

Etzelmüller, B., Farbrot, H., Guðmundsson, Á., Humlum, O., Tveito, O.E., Björnsson, H. 2007. The regional distribution of mountain permafrost in Iceland. Permafrost and Periglacial Processes 18 (2), 185-199. http://doi.org/10.1002/ppp.583.

Eypórsson, J. 1931. On the present position of the glaciers in Iceland: some preliminary studies and investigations in the summer 1930. Vísindafélag Isl, Rit, p 10, Reykjavik.

Eypórsson, J. 1935. On the Variations of Glaciers in Iceland. Some Studies Made in 1931. Geografiska Annaler 17, 121. Doi:10.2307/519954

Farinotti, D., Huss, M., Bauder, A., Funk, M., Truffer, M. 2009. A method to estimate ice volume and ice thickness distribution of alpine glaciers. Journal of Glaciology 55 (191), 422-430. https://doi.org/10.3189/002214309788816759.

Fernández-Fernández, J.M., Andrés, N., Sæmundsson, P., Brynjólfsson, S., Palacios, D. 2017. High sensitivity of North Iceland (Tröllaskagi) debris-free glaciers to climatic change from the "Little Ice Age" to the present. The Holocene 27 (8), 1187-1200. https://doi. org/10.1177/0959683616683262.

Francou, B., Vincent, C. 2007. Les glaciers à l'épreuve du climat, IRD Editions. http://books. openedition.org/irdeditions/9972.

Gabbud, C., Micheletti, N., Lane, S.N. 2016. Response of a temperate alpine valley glacier to climate change at the decadal scale. Geografiska Annaler: Series A, Physical Geography 98 (1), 81-95. http://doi.org/10.1111/geoa.12124.

Gachev, E., Stoyanov, K., Gikov, A. 2016. Small glaciers on the Balkan Peninsula: State and changes in the last several years. Quaternary International 415, 33-54. http://doi. org/10.1016/j.quaint.2015.10.042.

Geirsdóttir, Á., Miller, G.H., Axford, Y., Ólafsdóttir, S. 2009. Holocene and latest Pleistocene climate and glacier fluctuations in Iceland. Quaternary Science Reviews 28 (21-22), 2107 2118. https://doi.org/10.1016/j.quascirev.2009.03.013.

Gjermundsen, E.F., Mathieu, R., Kääb, A., Chinn, T., Fitzharris, B., Hagen, J.O. 2011. Assessment of multispectral glacier mapping methods and derivation of glacier area changes, 1978-2002, in the central Southern Alps, New Zealand, from ASTER satellite data, field survey and existing inventory data. Journal of Glaciology 57 (204), 667-683. https://doi. org/10.3189/002214311797409749.

Glenn, J.W. 1958. The flow law of ice: A discussion of the assumptions made in glacier theory, their experimental foundations and consequences, in: International Association of Scientific Hydrology. International Association of Scientific Hydrology Publication 47 (Symposium at Chamonix 1958 - Physics of the Movement of the Ice), pp. 171-183. http://go.owu. edu/ chjackso/Climate/papers/Glen_1958_The\%20flow\%20law\%20of\%20ice.pdf.

Häberle, T. 1991. Holocene Glacial History of the Hörgárdalur Area, Tröllaskagi, Northern Iceland. In: J.K. Maizels, C. Caseldine (Eds.), Environmental Change in Iceland: Past and Present. Springer Netherlands, Dordrecht, pp. 193-202. http://doi.org/10.1007/978-94-0113150-6_13.

Hannesdóttir, H., Björnsson, H., Pálsson, F., Aðalgeirsdóttir, G., Guðmundsson, S. 2015. Variations of southeast Vatnajökull ice cap (Iceland) 1650-1900 and reconstruction of the glacier 
surface geometry at the Little Ice Age maximum. Geografiska Annaler: Series A, Physical Geography 97 (2), 237-264. http://doi.org/10.1111/geoa.12064.

Holmlund, P. 1987. Mass Balance of Storglaciaren during the 20th Century. Geografiska Annaler. Series A, Physical Geography 69 (3-4), 439. http://doi.org/10.2307/521357.

Houghton, J.T., Meira Filho, L.G., Callander, B.A., Harris, N., Kattenberg, A., Maskell, K. 1996. Climate Change 1995: The Science of Climate Change. Contribution of Working Group I to the Second Assessment Report of the Intergovernmental Panel on Climate Change. Published for the Intergovernmental Panel on Climate Change, Cambridge University Press, Cambridge, 572 pp.

Hughes, P.D. 2008. Response of a Montenegro glacier to extreme summer heatwaves in 2003 and 2007. Geografiska Annaler: Series A, Physical Geography 90, 259-267. http://doi. org/10.1111/j.1468-0459.2008.00344.x.

Hughes, P.D. 2009a. Loch Lomond Stadial (Younger Dryas) glaciers and climate in Wales. Geological Journal 44 (4), 375-391. http://dx.doi.org/10.1002/gj.1153

Hughes, P.D. 2009b. Twenty-first century glaciers and climate in the Prokletije Mountains, Albania. Arctic, Antarctic, and Alpine Research 41 (4), 455-459. https://doi.org/10.1657/1938-424641.4.455.

Hughes, P.D., Braithwaite, R.J. 2008. Application of a degree-day model to reconstruct Pleistocene glacial climates. Quaternary Research 69 (1), 110-116. https://doi.org/10.1016/j. yqres.2007.10.008.

Hughes, P.D., Woodward, J.C., Gibbard, P.L. 2006. Late Pleistocene glaciers and climate in the Mediterranean. Global and Planetary Change 50 (1-2), 83-98. https://doi.org/10.1016/j. gloplacha.2005.07.005.

Hughes, P.D., Woodward, J.C., van Calsteren, P.C., Thomas, L.E.,Adamson, K.R. 2010. Pleistocene ice caps on the coastal mountains of the Adriatic Sea. Quaternary Science Reviews 29 (2728), 3690-3708. https://doi.org/10.1016/j.quascirev.2010.06.032.

Icelandic Glaciological Society, 2017. Glacier termini variations data. Available at: http:// spordakost.jorfi.is (last access: 27/06/2017).

Icelandic Meteorological Office, 2017. Climatological data. Available at: http://en.vedur.is/ climatology/data/ (last access: 29/06/2017).

Icelandic Road and Coastal Administration, 2017. Climatological data. Available at: http://www. road.is/ (last access: 29/06/2017).

Institute of Marine Research, Norway, 2017. Available at: http://www.imr.no/en/imr (last access: 20/06/2017).

Jóhannesson, H., Sæmundsson, K. 1989. Geological map of Iceland. 1:500.000. Bedrock. Icelandic Institute of Natural History, Reykjavik. http://en.ni.is/geology/geological-maps/ maps-geology-600000.

Jóhannesson, T., Sigurðsson, O, 1998. Interpretation of glacier variations in Iceland 1930-1995. Jökull 45, 27-34. http://www.jokulljournal.is/40-49/J45p27-34.pdf

Kääb, A. 2005. Remote sensing of mountain glaciers and permafrost creep. Schriftenreihe Physische Geographie 48, 266 pp. http://folk.uio.no/kaeaeb/publications/habil_screen.pdf.

Kääb, A., Huggel, C., Fischer, L., Guex, S., Paul, F., Roer, I., Salzmann, N., Schlaefli, S., Schmutz, K., Schneider, D., Strozzi, T., Weidmann, Y. 2005. Remote sensing of glacier- and permafrostrelated hazards in high mountains: an overview. Natural Hazards and Earth System Science 5, 527-554. https://doi.org/10.5194/nhess-5-527-2005.

Kaldybayev, A., Chen, Y., Vilesov, E. 2016. Glacier change in the Karatal river basin, Zhetysu (Dzhungar) Alatau, Kazakhstan. Annals of Glaciology 57 (71), 11-19. https://doi. org/10.3189/2016AoG71A005. 
Kern, Z., László, P. 2010. Size specific steady-state accumulation-area ratio: An improvement for equilibrium-line estimation of small palaeoglaciers. Quaternary Science Reviews 29 (19-20), 2781-2787. https://doi.org/10.1016/j.quascirev.2010.06.033.

Kirkbride, M.P. 2002. Icelandic Climate and glacier fluctuations through the termination of the "Little Ice Age". Polar Geography 26 (2), 116-133. http://dx.doi.org/10.1080/789610134.

Klein, A.G., Isacks, B.L. 1998. Alpine glacial geomorphological studies in the central Andes using Landsat Thematic Mapper images. Glacial Geology and Geomorphology rp01. http://www. ibrarian.net/navon/paper/ALPINE_GLACIAL_GEOMORPHOLOGICAL_STUDIES_IN_ THE_CE.pdf?paperid=2546002.

Koblet, T., Gärtner-Roer, I., Zemp, M., Jansson, P., Thee, P., Haeberli, W., Holmlund, P. 2010. Reanalysis of multi-temporal aerial images of Storglaciären, Sweden (1959-99) - Part 1: Determination of length, area, and volume changes. The Cryosphere 4, 333-343. https://doi. org/10.5194/tc-4-333-2010.

Kugelmann, O. 1991. Dating Recent glacier advances in the Svarfadardalur-Skíđadalur area of Northern Iceland by means of a new lichen curve. In: J.K. Maizels, C. Caseldine (Eds.), Environmental Change in Iceland: Past and Present. Springer Netherlands, Dordrecht, pp. 203-217. https://doi.org/10.1007/978-94-011-3150-6_14.

Lie, O., Dahl, S.O., Nesje, A. 2003. A Theoretical Approach to Glacier Equilibrium-Line Altitudes Using Meteorological Data and Glacier Mass-Balance Records from Southern Norway. The Holocene 13 (3), 365-372. https://doi.org/10.1191/0959683603hl629rp.

Liestøl, O. 1967. Storbreen glacier in Jotunheimen, Norway. Norsk Polarinstitutt Skrifter nr. 141, 1-63.

Mal, S., Singh, R.B., Schickhoff, U. 2016. Estimating Recent Glacier Changes in Central Himalaya, India, Using Remote Sensing Data. In: Climate Change, Glacier Response, and Vegetation Dynamics in the Himalaya. Springer International Publishing, Cham, pp. 205-218. https:// doi.org/10.1007/978-3-319-28977-9_11.

Martin, H.E., Whalley, W.B., Caseldine, C. 1991. Glacier Fluctuations and Rock Glaciers in Tröllaskagi, Northern Iceland, with Special Reference to 1946-1986. In: J.K. Maizels, C. Caseldine (Eds.), Environmental Change in Iceland: Past and Present. Springer Netherlands, Dordrecht, pp. 255-265. https://doi.org/10.1007/978-94-011-3150-6_17.

Meier, M.F., Bahr, D.B. 1996. Counting Glaciers: Use of Scaling Methods to Estimate the Number and Size Distribution of the Glaciers of the World. In: S.C. Colbeck (Ed.), Glaciers Ice Sheets and Volcanoes A Tribute to Mark F Meier. pp. 89-94.

Meyer, V.D., Barr, I.D. 2017. Linking glacier extent and summer temperature in NE Russia Implications for precipitation during the global Last Glacial Maximum. Palaeogeography, Palaeoclimatology, Palaeoecology 470, 72-80. https://doi.org/10.1016/j.palaeo.2016.12.038.

Mills, S.C., Grab, S.W., Rea, B.R., Carr, S.J., Farrow, A. 2012. Shifting westerlies and precipitation patterns during the Late Pleistocene in southern Africa determined using glacier reconstruction and mass balance modelling. Quaternary Science Reviews 55, 145-159. https://doi.org/10.1016/j.quascirev.2012.08.012.

Möller, M., Schneider, C. 2010. Calibration of glacier volume-area relations from surface extent fluctuations and application to future glacier change. Journal of Glaciology 56, 33-40. https:// doi.org/10.3189/002214310791190866.

Nesje, A. 1992. Topographical effects on the equilibrium-line-altitude on glaciers. GeoJournal 27 (4), 383-391. https://doi.org/10.1007/BF00185102.

Oerlemans, J. 2005. Extracting a climate signal from 169 glacier records. Science 308 (5722), 675677. https://doi.org/10.1126/science.1107046.

Ohmura, A., Kasser, P., Funk, M. 1992. Climate at the Equilibrium Line of Glaciers. Journal of Glaciology 38 (130), 397-411. https://doi.org/10.3189/S0022143000002276. 
Osmaston, H. 2005. Estimates of glacier equilibrium line altitudes by the areaxaltitude, the areaxaltitude balance ratio and the areaxaltitude balance index methods and their validation. Quaternary International 138-139, 22-31. https://doi.org/10.1016/j.quaint.2005.02.004.

Pellika, P., Rees, W.G. 2009. Remote Sensing of Glaciers: Techniques for topographic, spatial and thematic mapping of glaciers. Taylor \& Francis. http://doi.org/10.1201/b10155.

Pellitero, R. 2013. Evolución finicuaternaria del glaciarismo en el macizo de Fuentes Carrionas (Cordillera Cantábrica), propuesta cronológica y paleoambiental. Cuaternario y Geomorfología 27, 71-90. https://recyt.fecyt.es//index.php/CUGEO/article/view/20179.

Pellitero, R., Rea, B.R., Spagnolo, M., Bakke, J., Hughes, P., Ivy-Ochs, S., Lukas, S., Ribolini, A. 2015. A GIS tool for automatic calculation of glacier equilibrium-line altitudes. Computers \& Geosciences 82, 55-62. https://doi.org/10.1016/j.cageo.2015.05.005.

Pellitero, R., Rea, B.R., Spagnolo, M., Bakke, J., Ivy-Ochs, S., Frew, C.R., Hughes, P., Ribolini, A., Lukas, S., Renssen, H. 2016. GlaRe, a GIS tool to reconstruct the 3D surface of palaeoglaciers. Computers and Geosciences 94, 77-85. https://doi.org/10.1016/j.cageo.2016.06.008.

Qureshi, M.A., Yi, C., Xu, X., Li, Y. 2017. Glacier status during the period 1973-2014 in the Hunza Basin, Western Karakoram. Quaternary International 444, 125-136. https://doi. org/10.1016/j.quaint.2016.08.029.

Rabatel, A., Bermejo, A., Loarte, E., Soruco, A., Gomez, J., Leonardini, G., Vincent, C., Sicart, J.E. 2012. Can the snowline be used as an indicator of the equilibrium line and mass balance for glaciers in the outer tropics? Journal of Glaciology 58 (212), 1027-1036. http://doi. org/10.3189/2012JoG12J027.

Rabatel, A., Dedieu, J.P., Christian, V. 2016. Spatio-temporal changes in glacier-wide mass balance quantified by optical remote sensing on 30 glaciers in the French Alps for the period 19832014. Journal of Glaciology 62, 1153-1166. https://doi.org/10.1017/jog.2016.113.

Radić,V.,Hock,R., Oerlemans, J.2007. Volume-area scaling vs flowline modelling in glacier volume projections.Annals of Glaciology46,234-240.https://doi.org/10.3189/172756407782871288.

Rea, B.R. 2009. Defining modern day Area-Altitude Balance Ratios (AABRs) and their use in glacier-climate reconstructions. Quaternary Science Reviews 28 (3-4), 237-248. https://doi. org/10.1016/j.quascirev.2008.10.011.

Rodríguez-Rodríguez, L., Jiménez-Sánchez, M., Domínguez-Cuesta, M.J., Rinterknecht, V., Pallàs, R., Bourlès, D. 2016. Chronology of glaciations in the Cantabrian Mountains (NW Iberia) during the Last Glacial Cycle based on in situ-produced ${ }^{10} \mathrm{Be}$. Quaternary Science Reviews 138, 31-48. https://doi.org/10.1016/j.quascirev.2016.02.027.

Sæmundsson, K., Kristjansson, L., McDougall,I., Watkins, N.D. 1980. K-Ar dating, geological and paleomagnetic study of a 5-km lava succession in northern Iceland. Journal of Geophysical Research: Solid Earth 85 (B7), 3628-3646. http://doi.org/10.1029/JB085iB07p03628.

Sagredo, E.A., Lowell, T. V., Kelly, M.A., Rupper, S., Aravena, J.C., Ward, D.J., Malone, A.G. 2017. Equilibrium line altitudes along the Andes during the Last millennium: Paleoclimatic implications. The Holocene 27 (7), 1019-1033. https://doi.org/10.1177/0959683616678458.

Santos-González, J., Redondo-Vega, J.M., González-Gutiérrez, R.B., Gómez-Villar, A. 2013. Applying the AABR method to reconstruct equilibrium-line altitudes from the last glacial maximum in the Cantabrian Mountains (SW Europe). Palaeogeography, Palaeoclimatology, Palaeoecology 387, 185-199. https://doi.org/10.1016/j.palaeo.2013.07.025.

Schilling, D.H., Hollin, J. 1981. Numerical reconstructions of valley glaciers and small ice caps. In: T. Hughes, G.H. Denton (Eds.), The Last Great Ice Sheets. John Wiley and Sons, New York, pp. 207-220.

Sigurðsson, O. 1998. Glacier variations in Iceland 1930-1995. Jökull 45, 3-25. http://www. jokulljournal.is/40-49/J45p3-25.pdf. 
Sigurđsson, O., Jónsson, T., Jóhannesson, T. 2007. Relation between glacier-termini variations and summer temperature in Iceland since 1930. Annals of Glaciology 46, 170-176. https://doi. org/10.3189/172756407782871611.

Sissons, J.B. 1974. A late glacial ice cap in the Central Grampians, Scotland. Transactions of the Institute of British Geographers 62, 95-114. http://dx.doi.org/10.2307/621517.

Sissons, J.B., Sutherland, D.G. 1976. Climatic inferences from former glaciers in the southeast Grampian Highlands, Scotland. Journal of Glaciology 17 (76), 325-346. https://doi. org/10.3189/S0022143000013617.

Stötter, J. 1990. Geomorphologische und landschaftsgeschichtliche Untersuchungen im Svarfaðardalur-Skiðadalur, Tröllaskagi, N-Island. Münchener Geographische Abhandlungen 9, 1-166.

Styllas, M.N., Schimmelpfennig, I., Ghilardi, M., Benedetti, L. 2016. Geomorphologic and paleoclimatic evidence of Holocene glaciation on Mount Olympus, Greece. The Holocene 26 (5), 709-721. https://doi.org/10.1177/0959683615618259.

Sutherland, D.G. 1984. Modern glacier characteristics as a basis for inferring former climates with particular reference to the Loch Lomond Stadial. Quaternary Science Reviews 3 (4), 291 309. https://doi.org/10.1016/0277-3791(84)90010-6.

Tanarro, L.M., Palacios, D., Andrés, N., Fernández, J.M.,Zamorano, J.J. 2017. Surface morphology and dynamic of debris-covered and rock glaciers in the Tröllaskagi Peninsula (northern Iceland). Geophysical Research Abstracts 19, EGU2017-10534. http://meetingorganizer. copernicus.org/EGU2017/EGU2017-10534.pdf.

Thompson, D., Tootle, G., Kerr, G., Sivanpillai, R., Pochop, L. 2011. Glacier Variability in the Wind River Range, Wyoming. Journal of Hydrologic Engineering 16 (10), 798-805. http:// doi.org/10.1061/(ASCE)HE.1943-5584.0000384.

Úbeda, J. 2011. El impacto del cambio climático en los glaciares del complejo volcánico Nevado Coropuna, (Cordillera Occidental de los Andes Centrales). PhD Thesis. Universidad Complutense de Madrid, Servicio de Publicaciones, Madrid, 583 pp. http://eprints.ucm. es/12076/1/T32668.pdf.

Van de Wal, R.S.W., Wild, M. 2001. Modelling the response of glaciers to climate change by applying volume-area scaling in combination with a high resolution GCM. Climate Dynamics 18 (3-4), 359-366. https://doi.org/10.1007/s003820100184.

Veettil, B.K., Wang, S., Bremer, U.F., de Souza, S.F., Simões, J.C. 2017. Recent trends in annual snowline variations in the northern wet outer tropics: case studies from southern Cordillera Blanca, Peru. Theoretical and Applied Climatology 129, 213-227. https://doi.org/10.1007/ s00704-016-1775-0. 